\title{
The investigation of psychometric properties of Frost Multidimensional Perfectionism Scale (FMPS)
}

\author{
Fatemeh Akhavan Abiri ${ }^{1}$, Mohammad Reza Shairi², Mohammad Gholami Fesharaki ${ }^{3}$ \\ 1-M.A. graduated in clinical psychology, Department of Psychology, Shahed Univers ity, Tehran, Iran. ORCID: \\ 0000-0002-1719-3676 \\ 2-Associate Professor, Department of Psychology, Shahed University, Tehran, Iran (Corresponding Author). \\ ORCID: 0000-0002-2037-3475Ｅ-mail: shairigm@gmail.com \\ 3-Assistant Professor, Department of Bio-statistics, Tarbiat Modares University, Tehran, Iran. ORCID: 0000- \\ 0003-0517-5718
}

Received: $27 / 10 / 2018$

Acce pted: 08/01/2019

\section{Abstract}

Introduction: Perfectionis $m$ is a capacity belonging with high action criteria and critical selfappraisals. It is necessary to check its psychometric properties in Iranian samples to use Frost Multidimensional Perfectionism Scale (FMPS) as perfectionism assessing tool.

Aim: The aim of current research has been the determination of FMPS psychometric properties in Iranian non-clinical samples.

Method: In this descriptive study, 304 B. A. and M. D. students of Shahed University completed FMPS. The methods internal consistency and splitting were utilized to investigate reliability of FMPS. The tools Experiences in Close Relationship-Revised and Five Facet Mindfulness Questionnaire, Short Cognitive Emotion Regulation Questionnaire and Depression, Anxiety and Stress Scale-21 item were applied to investigate convergent validity of FMPS. FMPS factorial structure was checked with Confirmatory Factor Analysis.

Results: Data analysis showed acceptable reliability and validity of FMPS in Iranian nonclinical samples. Six- factor structure of FMPS was also confirmed.

Conclusion: Findings of the current research confirmed the usage of FMPS in psychological research and clinical Trails.

Keywords: Validity, Reliability, Perfectionism, Confirmatory factor analysis

\footnotetext{
How to cite this article : Akhavan Abiri F, Shairi M R, Gholami Fesharaki M. The investigation of psychometric properties of Frost Multidimensional Perfectionism Scale (FMPS). Shenakht Journal of Psychology and Psychiatry. 2019; 6 (1): 87-106 URL :http://shenakht.muk.ac.ir/article-1-604-fa.pdf
}

Copyright ( 2018 the Author (s). Published by Kurdistan University of Medical Sciences. This is an open access article distributed under the terms of the Creative Commons Attribution-Non Commercial License 4.0 (CCBY-NC), where it is permissible to download, share, remix, transform, and buildup the work provided it is properly cited. The work cannot be used commercially without permission from the journal. 


\title{
بررسى ويزٔى هاى روانسنجى مقياس كمال ترايى جندبعدى فراست (FMPS)
}

\author{
فاطمه اخوانعبيرى'، محمدرضا شعيرى'، محمد غلامى فشار كى \\ ا. كارشناسى ارشد روانشناسى بالينى، كروه روانشناسى بالينى، دانشكاه شاهد، تهران، ايران.

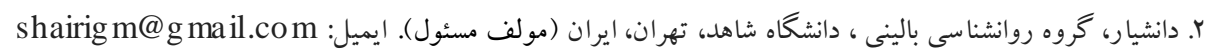

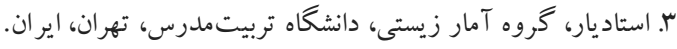

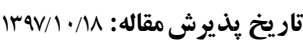 \\ تاريخ دريافت مقاله:ه.ه
}

جكيده

مقدمه: كمال گر ايى استعدادى متضمّن معيارهاى بالاى عمل و خودارزيابىهاى انتقادى است. مقياس كمال گر ايى جندبعدى

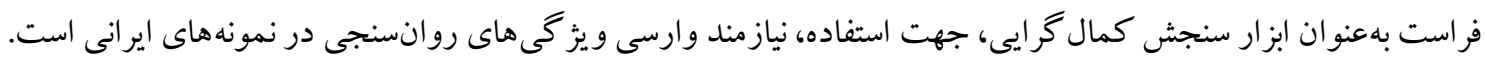
هدف: هدف يُزوهش حاضر، تعيين ويز گیىهاى روانسنجى مقياس كمال گر ايى جندبعدى فراست در نمونهاى غير بالينى ايرانى بوده است.

روش: در اين مطالعة توصيفى، مقياس كمال گر ايى جندبعدى فراست روى F.r.r دانشجوى كارشناسى و دكترى حرفهاى دانشكاه

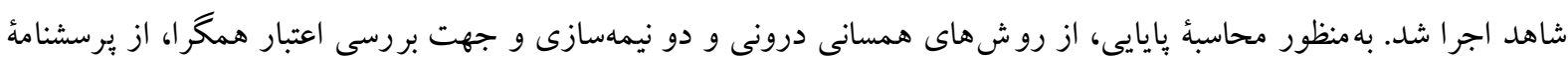

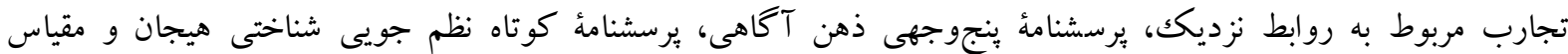

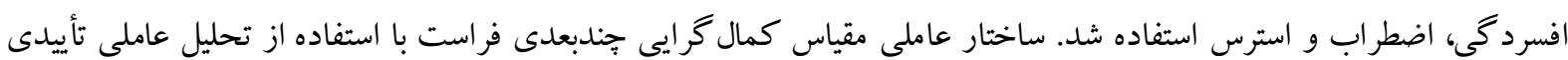
وارسى گرديد.

يافتهها: تحليل دادها اعتبار و بايايى قابل قبولى را از اين ابزار در نمونهُ غير بالينى ايرانى نشان داد... ساختار شش عاملى مقياس كمال گر ايى جندبعدى فراست نيز تأييد خرديد.

نتيجه كيرى: يافتههاى تحقيق حاضر مؤيّد استفاده از مقياس كمال گرايى خندبعدى فراست در يُوهشهاى روانشناختى و تلاش هاى بالينى است. كليدوازه ها: اعتبار، بايايى، كمال گرايى، تحليل عاملى تأييدى 


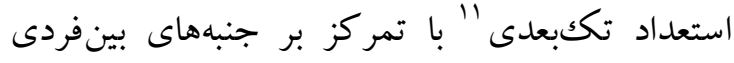

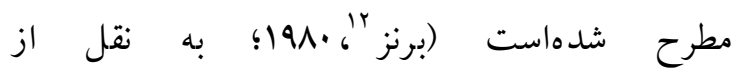

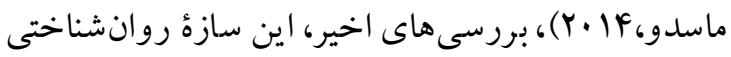

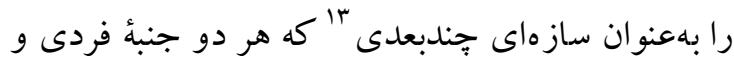

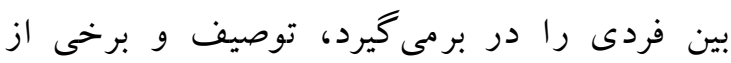

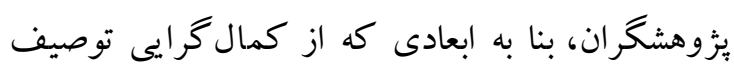

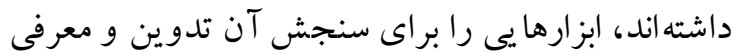
نمودهاند (فراست

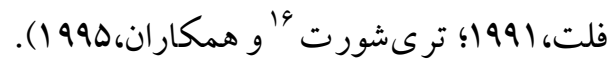

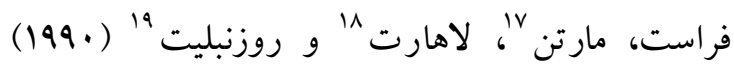

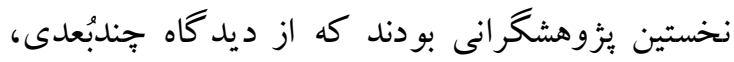

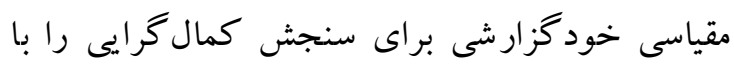

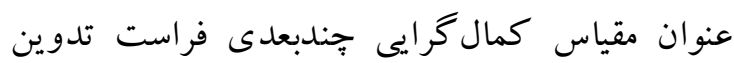
نمودند. اين مقياس ها گويه را در بر دارد كه در 4 عامل يا زيرمقياس گرووهبندى شدهاند؛ معيارهاى

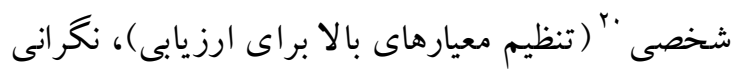

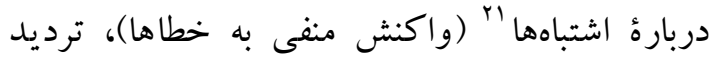

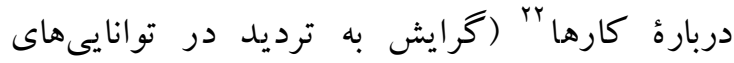

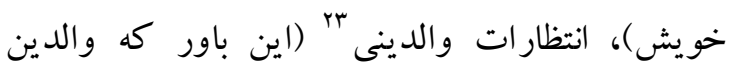
معيارهايى بسيار بالا در نظر گرفتهاند)، انتقادگرى باورى

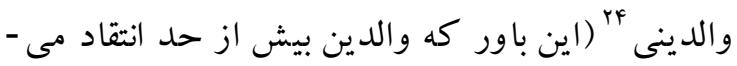

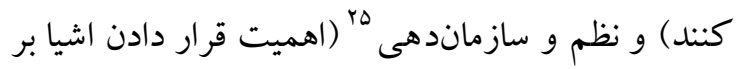

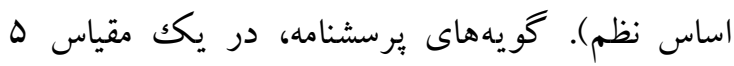

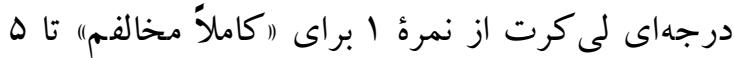

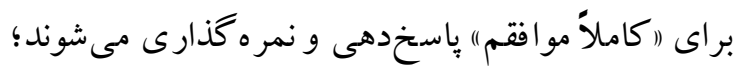

\footnotetext{
. unidimensional

. Berens, N. M.

. multidimensional

. Frost, R. O.

. Hewitt, P.L.

. Tery-Short, L. A.

. Marten, P.

. Lahart, C.

19 . Rosenblate, R.

20. Personal Standards (PS)

21 . Concern aver Mistakes (CM)

. Doubt about actions (D)

. Parental Expectations (PE)

24. Parental Criticism (PC)

. Organization $(\mathrm{O})$
}

مقلمه

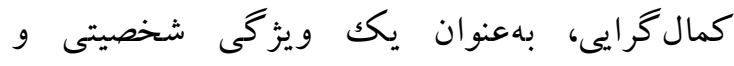

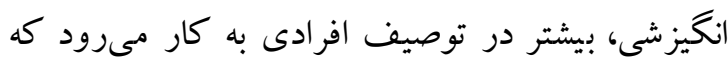
نكرانى زيادى دربارة خود و كارهايشان دارند، مجذوب كسب تأييد از ديخران هستند، به سختى خود را بىقيد و شرط مى بذيرند و كاه اين امر به ناتو انى در

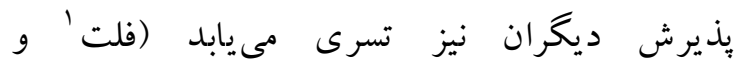

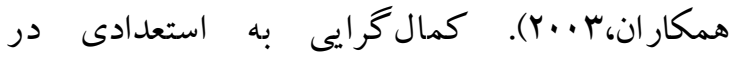
شخصيت اطلاق مى شود كه با معيارهاى بسيار بالا براى

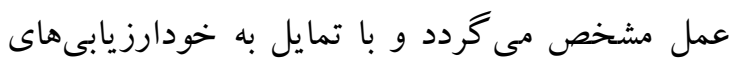

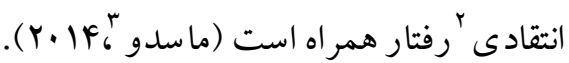
طى سه دهأ اخير، توجه و علاقهُ يُزوهشهاى حوزه:

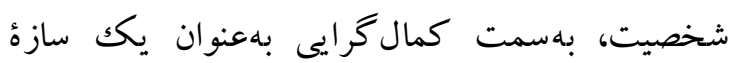

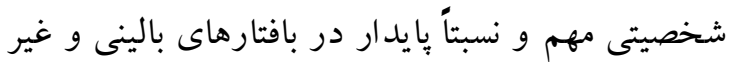
بالينى معطوف شده است. به نظر مىرسد كمال گررايى نقش عمدهاى در سببشناسى، تداوم و سير برخى

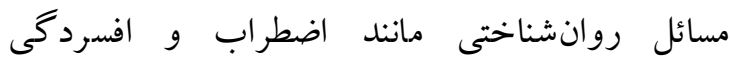

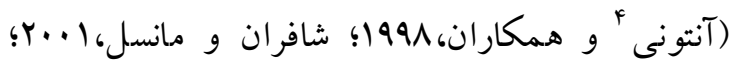

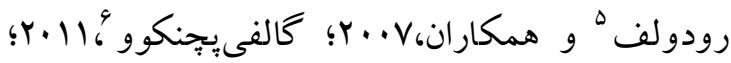

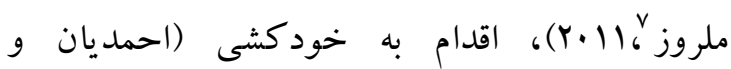

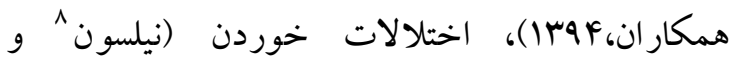

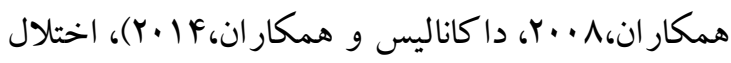
وسواس - بى اختيارى (يوسفى و همكاران،19+r؛

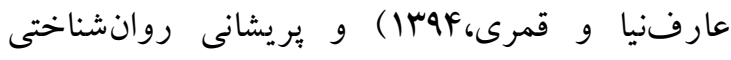

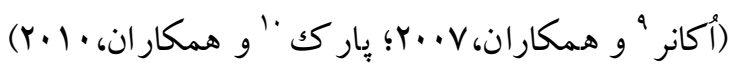

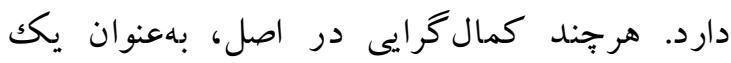

\footnotetext{
Flett, G. L.

critical self-evaluation

. Macedo, A.

. Antony, M. M.

. Rudolph, S. G.

. Galfi-Pechenkov, I

7 . Melrose, $\mathrm{S}$.

8 . Nilsson

9. O,connor, D. B

${ }_{10}$. Park, H. J.
} 
داخلى براى بررسى ويزگگهاى روانسنجى اين

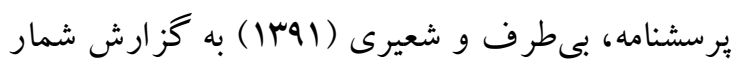

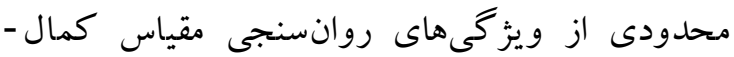
كرايى جندبعدى فراست برداختند و مقادير ضريب

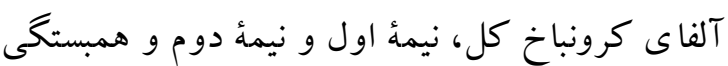
بين دو نيمةٔ مقياس كمال گر ايى جندبعدى فراست رابه

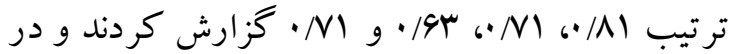
بررسى ساختار عاملى اين مقياس به ساختار 9 عاملى

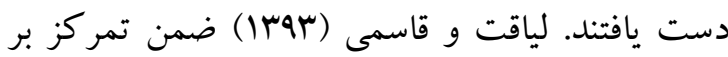
رابطة كمال گرايى و اضطراب امتحان و تأثير آنها بر يكديگر در نمونهُ دانش آموزى، ضريب همسانى درونى

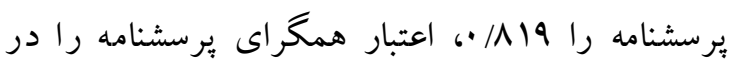

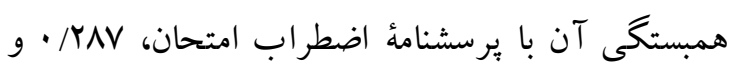

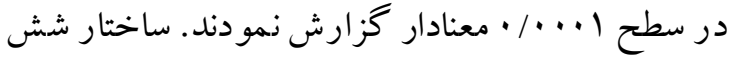
عاملى برسشنامه نيز در اين بزوهش مورد تأييد قرار

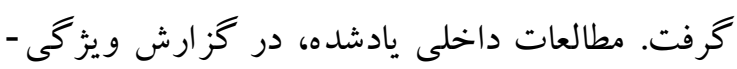
هاى روانسنجى مقياس كمال گر ايى جندبعدى فراست، به شاخصهاى مححدوى از اعتبار و يايايى بسنده نمودداند و به نظر مىرسد ضرورت مطالعهاى با تمركز

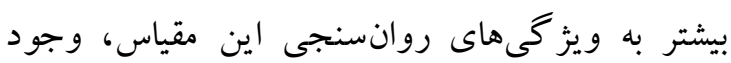

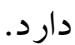
در ارزيابىهاى تجربى، برخى مطالعات، شو اهدى مبتنى

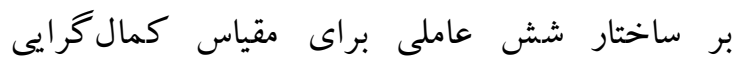

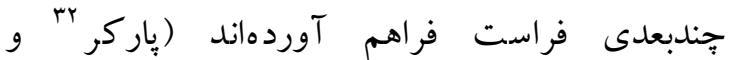

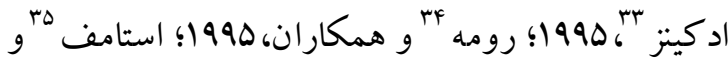

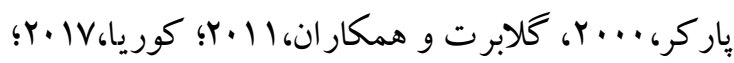
لياقت و قاسمى، بهم|)؛ با اين حال، برخى ديخر به نتايج متفاوتى در اين زمينه دست يافتهاند. بهعنوان مثال،

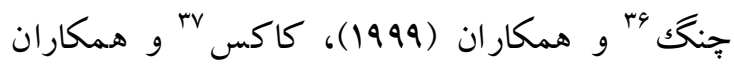

. Parker, W. D.

Adkins, K. K.

. Rhéaume, J.

. Stumpf, $\mathrm{H}$

36 . Cheng, S. K.

. Cox, B. J.
بنابراين، نمراتى كه از اين مقياس كسب مىشود، در

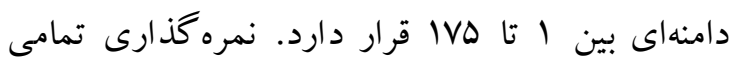
كويهها، بهصورت يككطر فه صورت مى گيرد. با وجود اين كه مرور ادبيات يزوهشى ويز گیىهاى

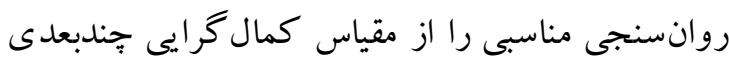

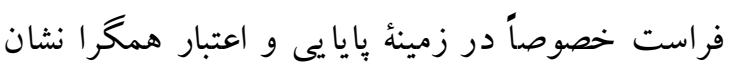
دادهاست، در يافتهاى حاصل از يُزوهشهاى معطوف به بررسى ساختار عاملى اين مقياس، اختلافنظر مشاهده مى شود. مطالعات مربوط به بررسى ويزگ گهاى روانسنجى اين مقياس، حاكى از اعتبار و پِايايى مناسبى از آن در نمونههاى مختلف هستند. در اين زمينه، در مطالعه

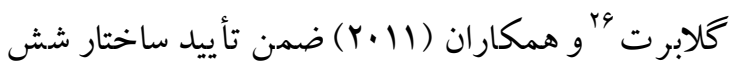
عاملى اين برسشنامه، ضريب همسانى درونى را براى

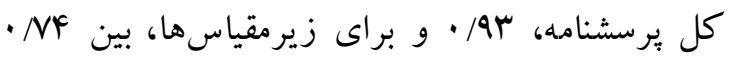
براى عامل ترديد دربارة كارها تا ا9 / •براى عامل نظم

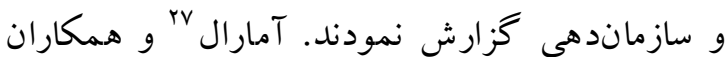

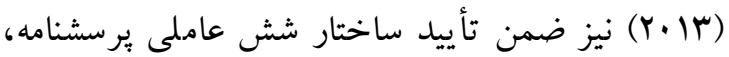
ضريب همسانى درونى آن رابراى كل مقياس، \$1 • • و

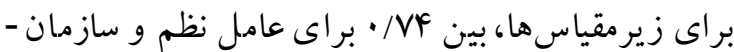

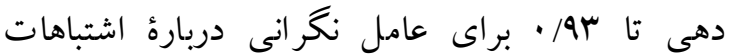

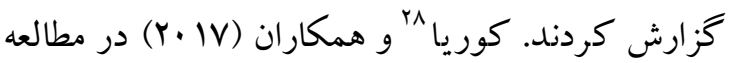
روى 9.r قهرمان ورزشى، اعتبار همخراى زيرمقياس هاى اين برسشنامه را بين /|/ • (در رابطة بين زيرمقياس نخر انى مقياس اضطراب ورزشى بو و زيرمقياس نظم و

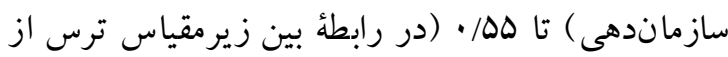

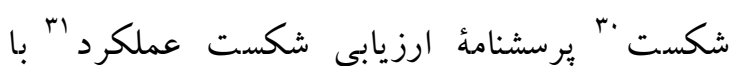

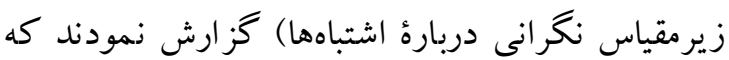

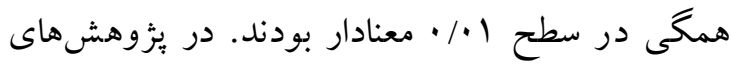

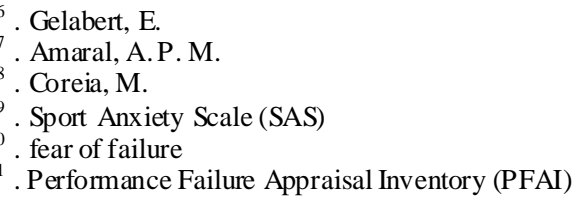

fear of failure

Performance Failure Appraisal Inventory (PFAI) 
بالينى دانشجويى از اعتبار و پِايايى مناسبى برخوردار

است؟

\section{روش}

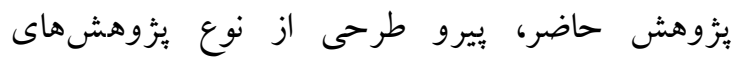

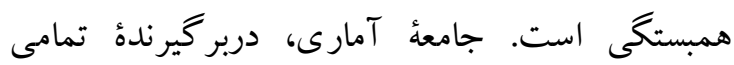
دانشجويان مقطع كارشناسى دانشگاه شاهد در سال تحصيلى 9V-9V94 بوده است. نمونهُ نهايى يزوهش

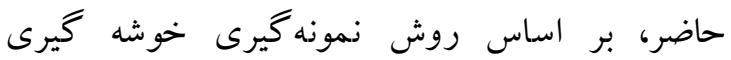
جندمرحلهاى انتخاب شدند و بر اين اساس تلاش شد تا با وجود ملاحظات و محدوديتهاى اجرا، نسبت افراد جامعه در هر خوشه، در نمونهُ انتخابشده رعايت

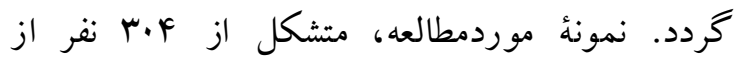
دانشجويان مقطع كارشناسى - و دكترى حرفهاى رشته هاى بز شكى و دندانيز شكى - بوده است كه در سال تحصيلى VV_9 بودهاند. نمونه شامل IY I نفر (Yץ/) از دانشجويان

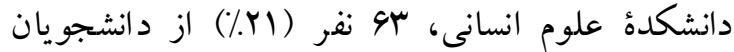

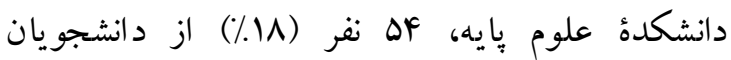

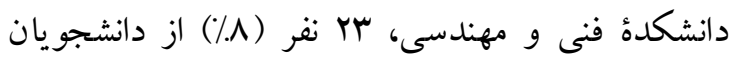

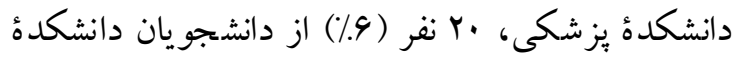

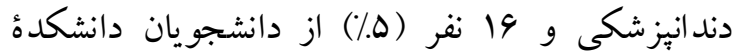
برستارى و مامايى بوده است. ملاككهاى ورود شركت كنندگان در يزوهش عبارت بودند از: دانشجو مائ بوده بودن، تحصيل در مقطع كارشناسى و دكترى حرفهاى،

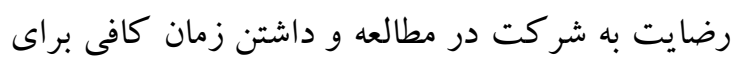
باسخ به برسشنامهها. ملاكك خروج نيز عبارت بود از: عدم تمايل به مشار كت در يزوهش. علاوه بر ملاكك هاى ورود و خروج براى شركت كنند كان، كدهاى مربوط به رضايت شركت كنند كان و هـمجنين رازدارى درباره نتايج هريكك از آنها كه در ضوابط اخلاقى رصى

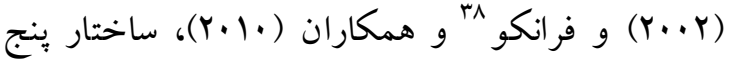

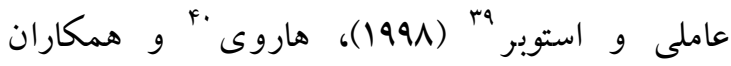
(Y..D) (Y...F)

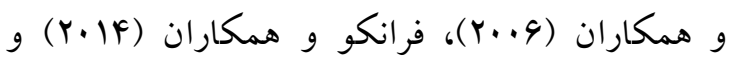

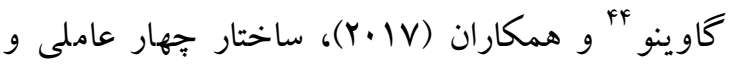

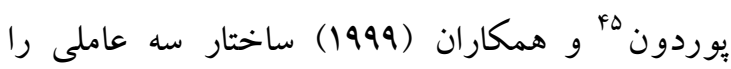
كزارش نمودند. بنا به اختلافنظر يادشده در زمينه

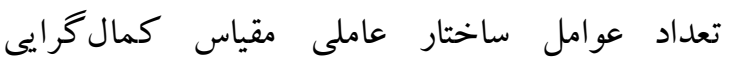
جندبعدى فراست، بررسى اين جنبه از ويزگى هاى روانسنجى مقياس كمال گرايى جندبعدى فراست نيز

$$
\text { يشنهاد مى گردد. }
$$

مرور شواهد يزّوهشى، ويزَّى هاى روانسنجى مناسب

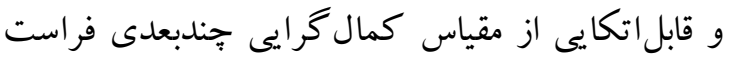
در موقعيتهاى مختلف و روى نمونهاى متفاوت، نشان مىدهد. با اين حال، در بحث از ساختار عاملى و شمار عوامل تشكيلدهندهٔ ساختار اين مقياس، در يثوهشهاى انجامشده، مناقشاتى وجود دارد. ضمن عنايت به كاربرد فراگير مقياس كمال گر ايى جندبعدى فراست در ئزوهشهاى خارجى و در نمونهاى مختلف، عدم دسترسى به مطالعهاى جامع در تعيين

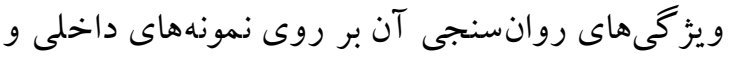

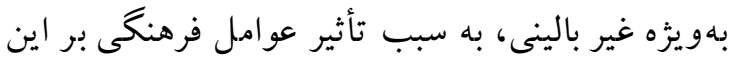

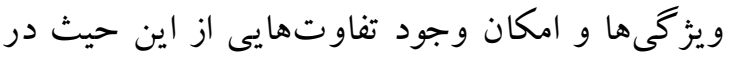
ميان فرهنكَهاى مختلف، ئزوهش حاضر باهدف تعبين

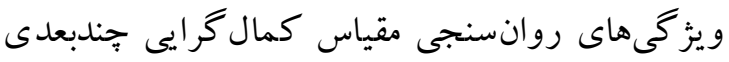

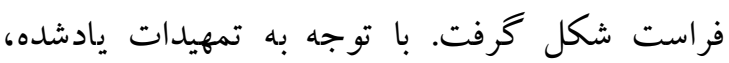
سؤال اساسى تحقيق حاضر اين است كه آيا مقياس كمال كرايى جندبعدى فراست (FMPS) در نمونهُ غير

\footnotetext{
Franco, K

. Stöber, J

40. Harvey, B.

. Khavaja, N. G

. Armstrong, K. A.

. Hawkins, C. C.

44 . Gavino, A

45 . Purdon, C.
} 
برسشنامه تجارب روابط نزديك هد (ECR-R): مقياس

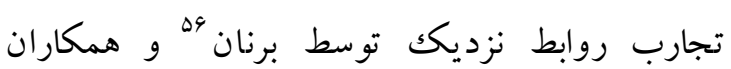

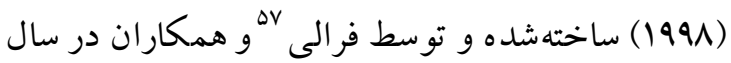

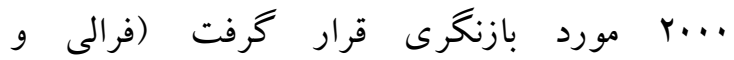

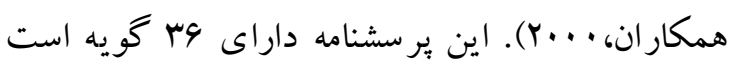

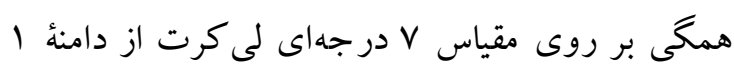

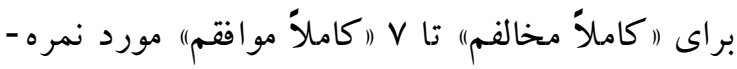

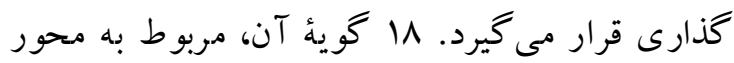

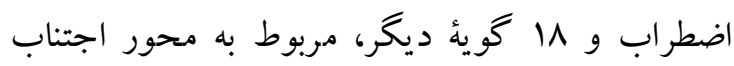
هستند. نمرات بالاتر، نشاندهنده سطح بالاترى از

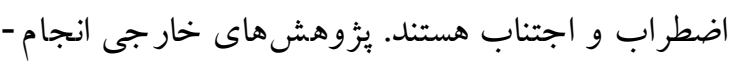

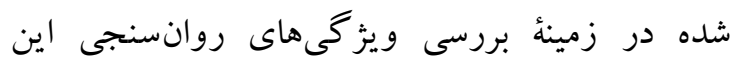

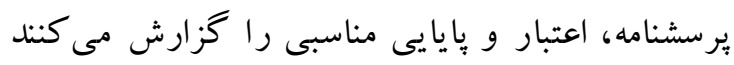

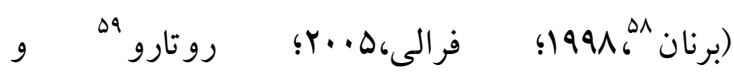

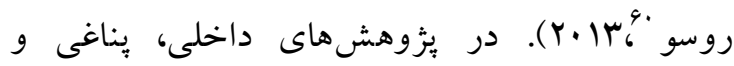

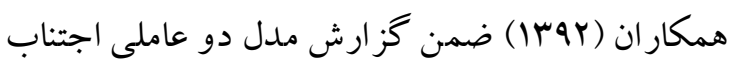
و اضطراب، ضريب همسانى درونى دو بعد اجتناب و ونى

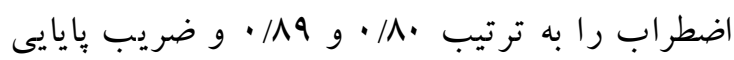

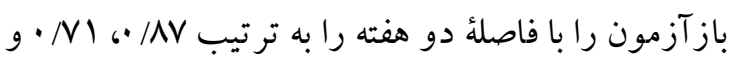

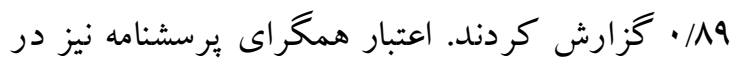

$$
\text { اغلب موارد معنادار گزارش شد. }
$$

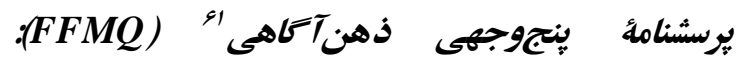

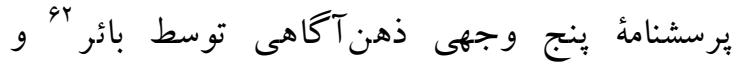

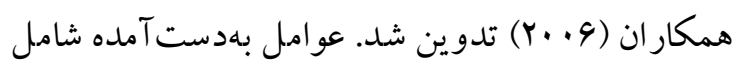

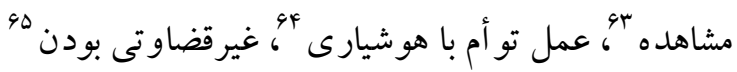

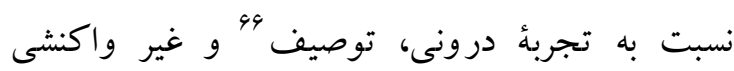

55 . Experiences of Close Relationship - Revised (ECR-R)

56 . Brennan, K. A.

. Fraley, R. C.

. Brennan, K. A

Rotaru, T.S.

60. Rusu, A.

. Five Facet Mindfulness Questionnaire (FFMQ)

62 . Baer, R. A

. observe

64 . act with awareness

65. non-judge

66 describe
انجمن روانيزشكى امريكا "F درجشدهاند، رعايت

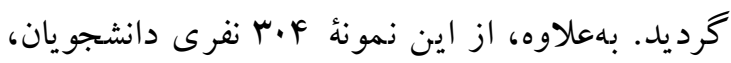

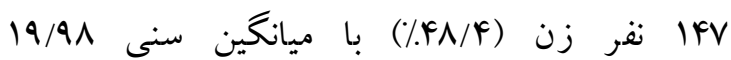

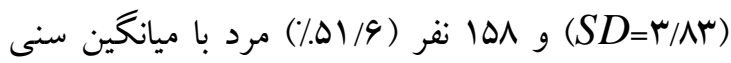
(SD=r/Ar) r r// r

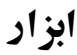

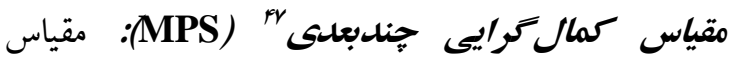

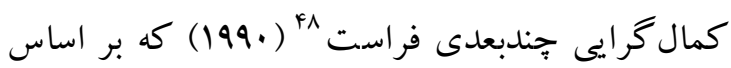

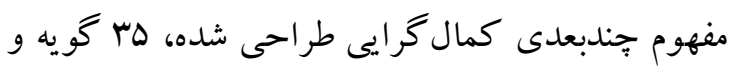
9بعد يا زيرمقياس را در بر مى گيرد. اين زيرمقياسها،

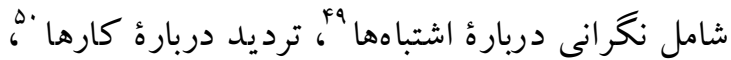

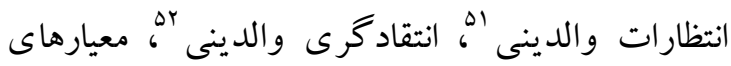

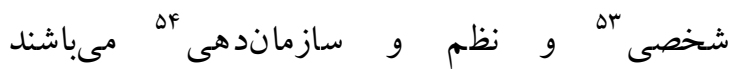

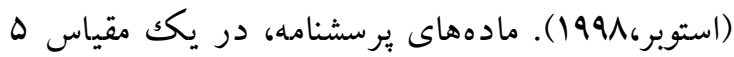

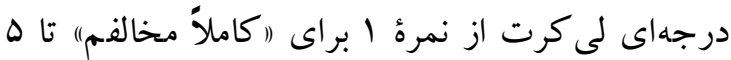

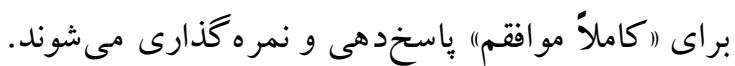

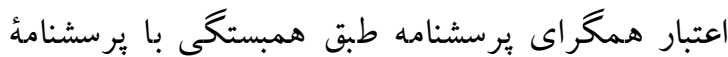

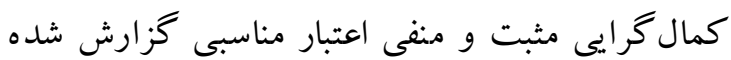

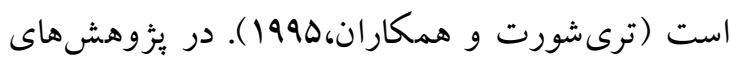

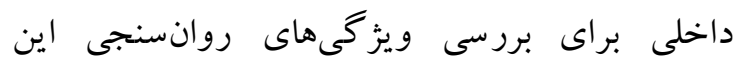

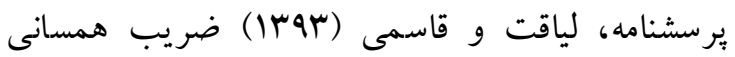

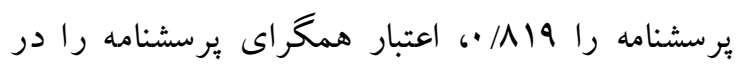

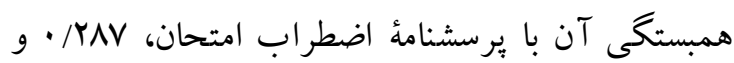

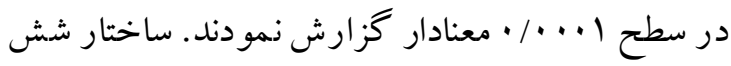
عاملى استاندارد بيشنهادشده توسط فراست و همكاران نيز در اين بزوهش مورد تأييد قرار كرفت.

\footnotetext{
46. American Psychiatric Association (APA)

. Multidimensional Perfectionism Scale (MPS)

48. Frost, R. O.

49. Concern over Mistakes (CM)

50 . Doubt about actions (D)

. Parental Expectations (PE)

. Parental Criticism (PC)

53 . Personal St andards (PS)

54 . Organization $(\mathrm{O})$
} 
(براون " و همكاران، 199r؛ آنتونى و همكاران، 1991؛ هنرى

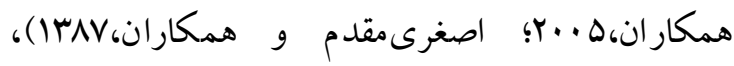
ويزّ كىهاى روانسنجى مناسبى گز ارش شدهاست. در ميان مطالعات داخلى، اصغرى مقدم و همكاران (I I ( در بررسى ويز گیىهاى روانسنجى اين مقياس، يايايى اين مقياس را به روش باز آزمايى با فاصلة سه هفته، براى زيرمقياسهاى افسردگى، اضطراب و استرس به

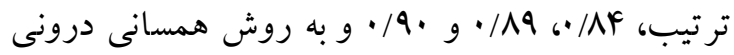

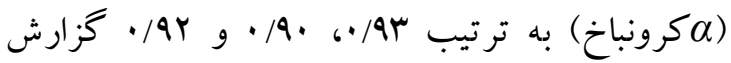
نمودهاند. اعتبار همكراى اين مقياس نيز در سطح

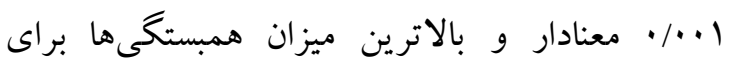

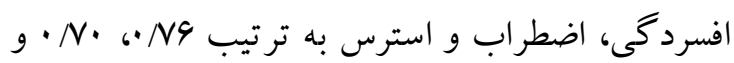

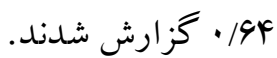

\section{فرم كوتاه برسشنامة نظمرجويى شناختى هيجان} (CERQ-S)

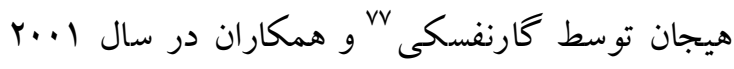

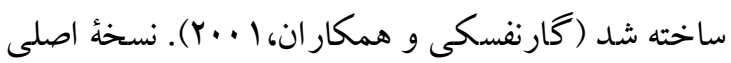
اين برسشنامه داراى وب گويه و از ه زيرمقياس تشكيل شدهاست. فرم كو تاه اين يرسشنامه، توسط كارنفسكى

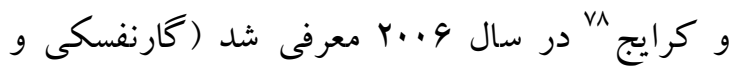

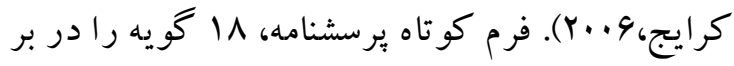
دارد و همانند نسخهُ اصلى، از وزيرمقياس تشكيل شده است. اين زيرمقياسها، راهبردهاى شناختى به شمار

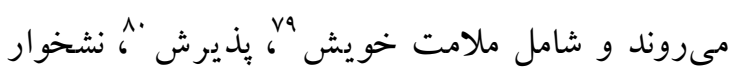

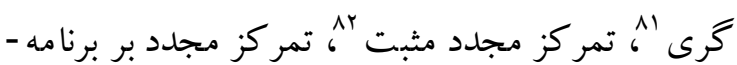

73. Brown, T. A

. Henry, J.

75 . Crawford, J. R.

${ }^{76}$. Cognitive Emotion Regulation Questionnaire- Short form (CERQ-S)

Garnefski, N

. Kraaij, V.

Self-blame

. Acceptance

. Rumination

82. Positive refocusing
بودن ولاست كه جهار عامل زخست، هريك ^ كويه و عامل بنجم، V Vو يه را در بردارند. در نهايت ير سشنامه اى با هب كويه بهدست آمد كه در مقياس ليكرت از 1 (هر گز)" تا ه (هميشه)) نمرهذذارى مىشود. مطالعات مربوط به بررسى ويز گیىهاى روانسنجى اين مقياس، اعتبار و وِيايیى مناسبى را از آن گزارش نمودهاند.

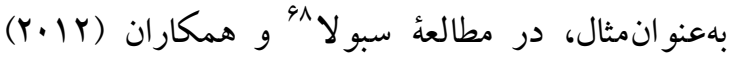
مدل ه عاملى برسشنامه تأييد شد و ضريب همسانى درونى در دو نمونهُ اسيانيايى و انخليسى، بهترتيب از •A/ • براى غير واكنشى بودن تا |9/· براى توصيف و

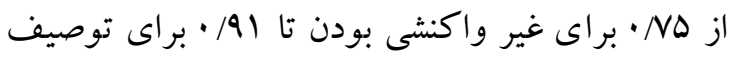
كز ارش شد. احمدوند، حيدرى نسب و شعيرى (r r Ir) ضريب همسانى درونى پرسشنامةُ ينجوجهى ذهن آكاهى را بين هه/· و سه/· و ضريب بازآزمايى اين

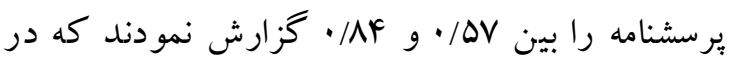
سطح 1 +•• معنادار بودند. اعتبار يرسشنامه نيز، در بيشتر موارد معنادار گزارش شد.

يرسشنامة افسردمحى، اضطر/ب و استرس "و (DASS-21). مقياس افسردكى، اضطراب و استرس در خلال يزّوهشى (19V9-1999) با هدف ايجاد يرسشنامهاى براى سنجش متغيرهاى يادشده، توسط لوىباند لم و لوىباند اv در سال سهو ا، تحت عنوان DASS-42 معرفى شد. به دليل ضعفهاى موجود در DASS-42. آنتونى " و همكاران (1991) طى تلاش خود، مقياس اب گويهاى افسردگى، اضطراب و استرس را ساختند كه هر سه زيرمقياس فرم قبلى را دار ابود و براى هر يكك V كويه در برداشت. نمره گذارى اين آزمون در دامنهاى از · (اصلاً) تا س (اخيلى زياد)) صورت مى گيرد. از اين مقياس، در مطالعات روانسنجى خارجى

\footnotetext{
non-react

68. Cebolla, A

. Depression, Anxiety and Stress Scale21 (DASS-21)

70 . Lovibond, P. F.

. Lovibond, S. H.

. Antony, M. M.
} 
شدند. ميانگين زيرمقياسهاى مقياس كمالگرايى جندبعدى فراست، از طريق آزمون تى - استيودنت با

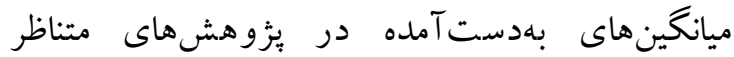

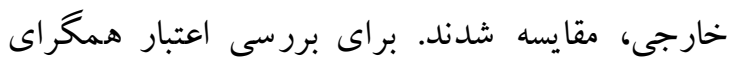

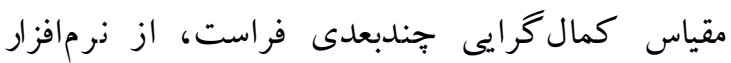

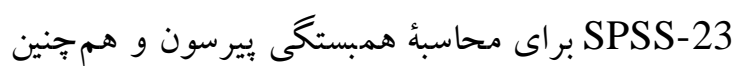

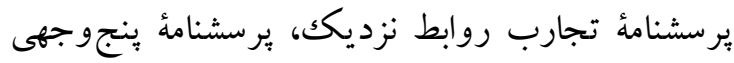

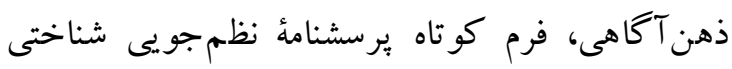
هيجان و مقياس افسردگىى، اضطراب و استرس استفاده

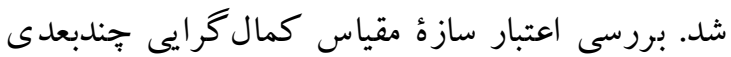

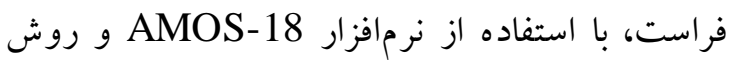

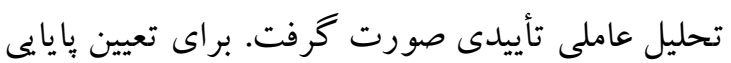
اين مقياس، از روش همسانى درونى (آلفاى كرونباخ) و دو نيمه سازى استفاده شد.

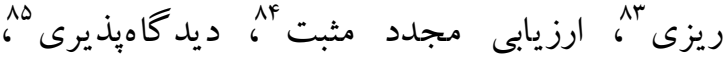

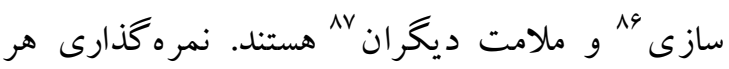

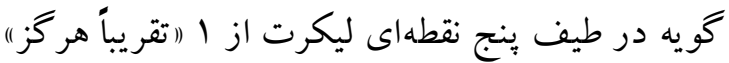

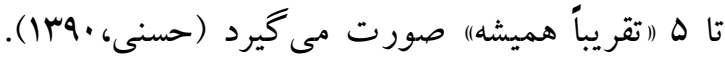

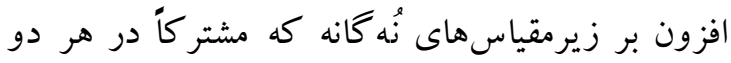
نسخه وجود دارد، در فرم كوتاه، دو راهبرد كلى بلى

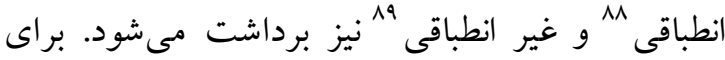

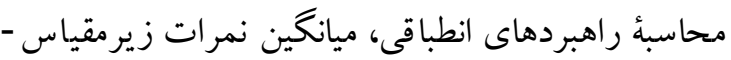

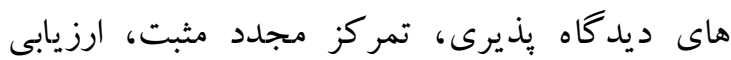
مجدد مثبت، بذيرش و تمركز مجدد بر برنامهريزى و براى محاسبة راهبردهاى غير انطباقى، ميانگين نمرات زيرمقياس هاى ملامت خو يش، ملامت ديخران، نشخوار

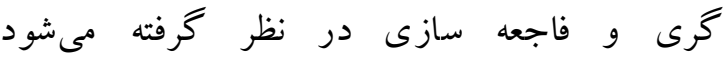

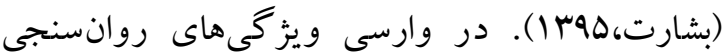
يرسشنامة كو تاه نظمجويى شناختى هيجان، كارنفسكى و كرايج (4. . (Y) ضريب آلفاى كرونباخ اين برسشنامه رابين ای/·و 91/· و اعتبار بيرونى آن را با استفاده از زيرمقياسهاى اضطراب و افسردىى سياهؤ نشانهاى

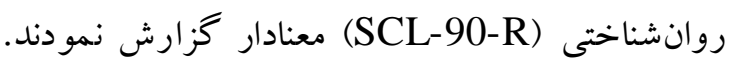
نسخهُ فارسى اين يرسشنامه طى مطالعه هنجاريابى

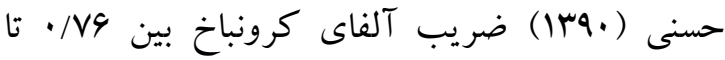

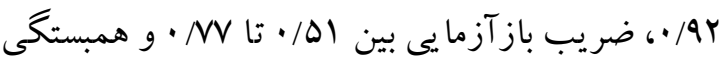

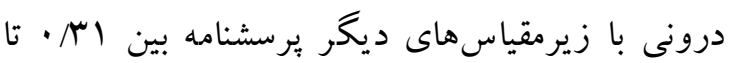

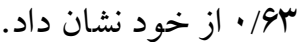

يافته ها جهت تحليل دادههاى ئزوهش حاضر، شاخصهاى

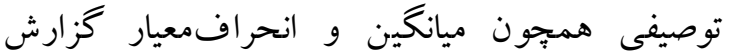

\footnotetext{
. Planning

. Positive reappraisal

. Putting into Perspective

. Cat astrophizing

87 . Other-blame

88. Adaptive strat egies

. Maladaptive strat egies
} 
جدول ا ميانكين و انحر اف معيار زيرمقياس ها مقياس كمال كرايى جندبعدى فر است در تحقيق حاضر و نموزههاى غيراير انى

\begin{tabular}{|c|c|c|}
\hline يخوهش كلابرت (l l • r) & يخوهش حاضر & \\
\hline$n=\Delta \wedge r$ & $n=r \cdot r$ & \\
\hline ميانگين (انحراف معيار) & ميانگين (انحراف معيار) & \\
\hline$(V / V Y) Y \cdot / \cdot q$ & ( & نكر انى دربارة اشتباهها \\
\hline$(r / 9 V) 11 / \cdot 1$ & $(r / T Y) \| N$. & ترديد درباره كارها \\
\hline$(F / 9 \wedge) 11 / 9$. & $(r / 94) 19 / 94$ & انتظارات والدينى \\
\hline$(r / 94) V / 4 r$ & $(Y / Q Y) Q / Y \Lambda$ & انتقاد كرى والدينى \\
\hline$(9 / N F) Y \cdot / r Y$ & $(r / 9 V) r q / 94$ & معيار هاى شخصى \\
\hline$(\Delta / V \Lambda) Y \cdot / / \Delta$ & $(r / q \Delta) r F / l$. & نظم و سازماند هى \\
\hline$(Y Y / F \Lambda) q \cdot N Y$ & $(|f / 9|) \mid 10 / 94$ & نمرة كل \\
\hline
\end{tabular}

جدول r مقايسة ميانكين زير مقياس هاى مقياس كمال ترايى جندبعدى فراست در نمونهُ ئوهش حاضر با نمونه هاى غير ايرانى

\begin{tabular}{|c|c|c|}
\hline 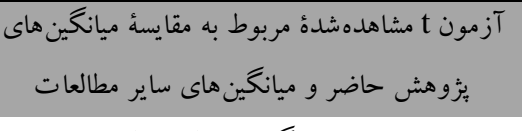 & ئوهش & رديف \\
\hline 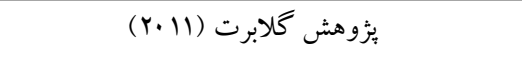 & زيرمقياس هاى آزمون & \\
\hline$n=\wedge \Delta r$ & & \\
\hline $1 \% / 10^{* * * * * *}$ & نخرانى دربارة اشتباهها & 1 \\
\hline$r / V q^{\text {****** }}$ & ترديد دربارة كارها & r \\
\hline $\mid F / F F^{\text {类彞 }}$ & 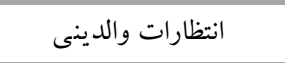 & $r$ \\
\hline$V / 9 Y^{* * *}$ & انتقاد كرى والدينى & p \\
\hline IV/rN & 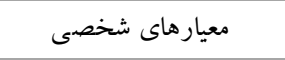 & $\Delta$ \\
\hline $1 \cdot 191^{* * *}$ & نظم و سازماندهى & 9 \\
\hline $\mid V / F V^{* * * * * a *}$ & 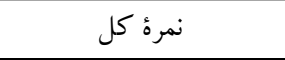 & $\checkmark$ \\
\hline
\end{tabular}

كر ايى جندبعدى فراست، با ميانگين هاى متناظر در ساير

يثزوهش هاى يادشده تفاوت معنادار و جود دارد.

$$
\begin{aligned}
& \mathrm{p}<\cdot / \cdot)^{* * *} \quad \mathrm{p}<\cdot / \cdot \Delta^{*} \\
& \text { نتايج مندرج در جدول r نشان مىدهد كه بين ميانگين - } \\
& \text { هاى مربو ط به هريك از زيرمقياس هاى مقياس كمال - }
\end{aligned}
$$

جدول همبستكى بين زير مقياس هاى مقياس كمال كرايى جندبعدى فر است با يكديكر

زيرمقياس هاى برسشنامه




\begin{tabular}{|c|c|c|c|c|c|c|c|}
\hline & & & 1 & $\cdot / \pi \Delta^{* * * *}$ & $\cdot / A F^{* * * *}$ & $\cdot|f|^{* * * *}$ & نتقادگرى والدينى \\
\hline & & 1 & $-\cdot / \cdot r$ & $\cdot 119^{* * * *}$ & $\cdot / \mu^{* * * * a r}$ & $\cdot / Y F^{* * * * *}$ & معيارهاى شخصى \\
\hline & 1 & $\cdot \pi \Lambda^{* * * * *}$ & 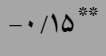 & $\cdot / \cdot r$ & $\cdot / \cdot f$ & $-\cdot / \cdot 1$ & نظم و سازماندهى \\
\hline 1 & 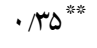 & 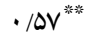 & $\cdot / \Delta r^{* * * * w^{*}}$ & $\cdot / \Delta F^{* * * *}$ & $\cdot / \cdot^{* * * * * 6}$ & 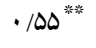 & نمرة كل \\
\hline
\end{tabular}

مقياس هاى نخر انى درباره اشتباهها، ترديد درباره كارها و انتظارات والدينى و نيز زير مقياس معيارهاى شخصى با زير مقياس انتقادگرى والدينى رابطة معنادار ندارند.
نتايج مندرج در جدول م همبستخى معنادار بين زير

مقياسهاى مقياس كمال نشان مىدهد. البته زير مقياس نظم و ترتيب با زير

جدول F همبتكى زيرمقياسهاى مقياس كمال كرايع جندبعدى فر است با زير مقياس هاى ديكر ابزارها

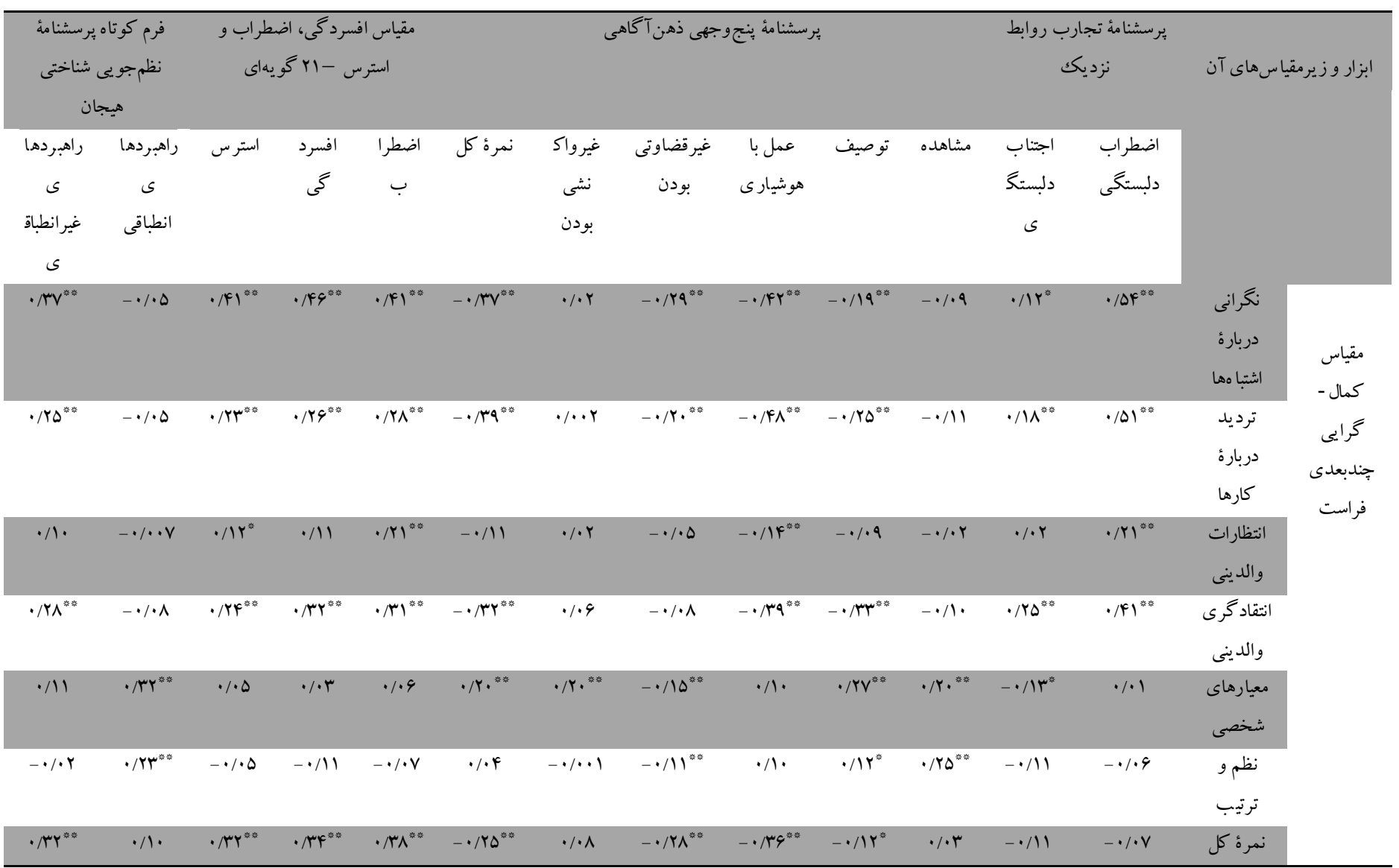

$$
\mathrm{p}<\cdot / \cdot)^{\text {**** }} \mathrm{p}<\cdot / \cdot \Delta^{*}
$$

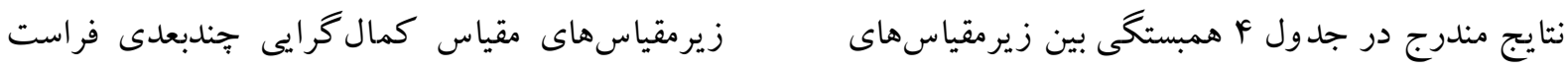

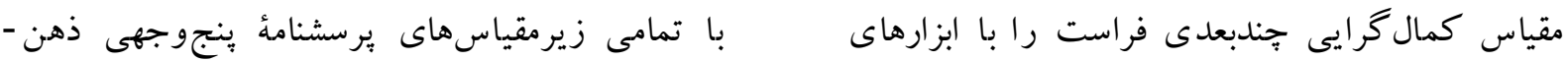

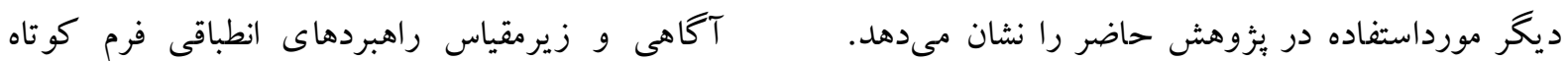

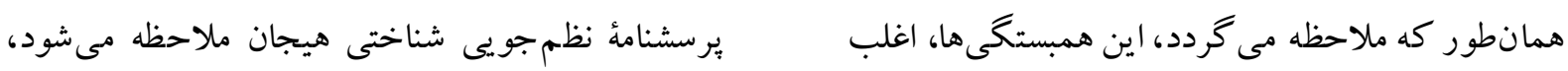

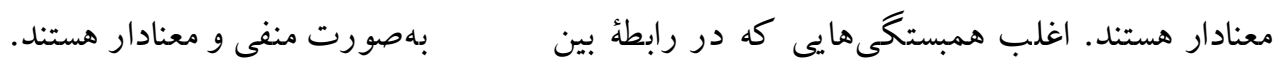


جدوله ضر ايب آلفاى كرونباخ و دو نيمهسازى زيرمقياسهاى مقياس كمال كرايى جندبعدى فر است

\begin{tabular}{|c|c|c|}
\hline 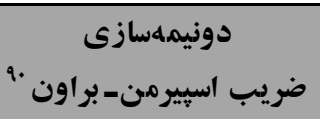 & كرونباخ & زيرمقياس \\
\hline • & $\cdot / A \cdot$ & نترانى دربارة اشتباهها \\
\hline .199 & .194 & ترديد دربارؤ كار ها \\
\hline$\cdot M^{F}$ & $\cdot M^{F}$ & انتظارات والدينى \\
\hline$\cdot M^{F}$ & .199 & انتقاد كرى والدينى \\
\hline .194 & .199 & معيار هاى شخصى \\
\hline • & $\cdot|A|$ & نظم و ترتيب \\
\hline · / & $\cdot / A F$ & نمرة كل \\
\hline
\end{tabular}

جدول 4 شاخص هاى برازش مدل تأييدى ساختار شش عاملى مقياس كمال كرايى جندبعدى فر است

\begin{tabular}{|c|c|c|c|c|c|c|c|}
\hline خطاى بر بآور ميانكين مربّعات & هنجارشده & تطبيقى & 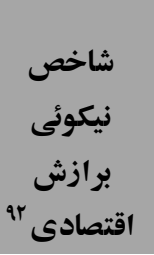 & خى -دوى نسبى & 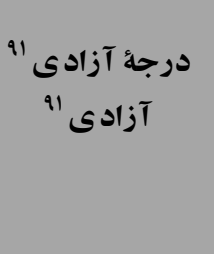 & خى -دو & شاخص \\
\hline $\begin{array}{c}. / .9 Y \\
(\cdot 1 \cdot 0 \Lambda-\cdot 1.9 \mathrm{~V})\end{array}$ & $.191 \mathrm{~F}$ & $\cdot / \mathrm{VIV}$ & .1999 & $r / M$. & $\Delta{ }^{\prime} \Lambda$ & $11 n / .10$ & 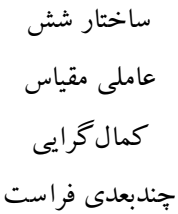 \\
\hline
\end{tabular}

. Spearman-Brown Coefficient

. Degree of Freedom

. Parsimonious Goodness of Fit Index (PGFI)

. Parsimonious Comparative Fit Index (PCF)

94. Parsimonious Normed Fit Index (PNFI)

95 . Root Mean Square Error Approximation (RMSEA) 
معيارهاى شخصى كه در سطح (+.) • معنادار است) معنادار مىباشند. ئزوهش يادشده به اين دليل كه در برخى بثزوهشها مورد اشاره قرار گرفتند، براى مقايسٔ

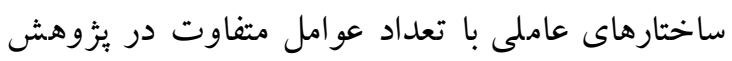

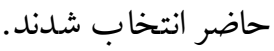
جدول V شاخص هاى برازش مدلهاى شش عاملى

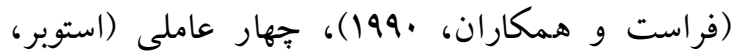

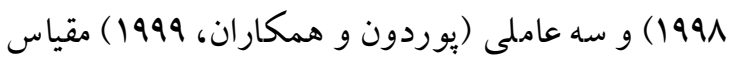

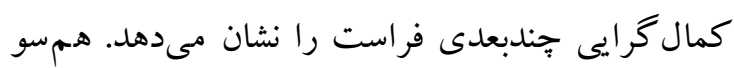
با ادبيات يُزوهشى، مدل شش عاملى اوليه بر روى داده هاى حاصل از يزوهش حاضر نيز مورد تحليل قرار

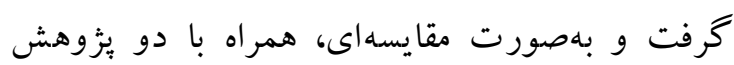

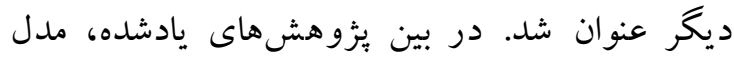

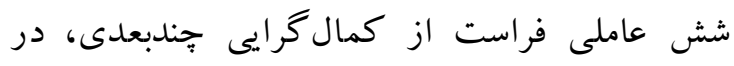
يُزوهش كوريا و همكاران (Y.IV) با خى -دوى نسبى كمتر از Y (تباجنيكك و فيدل،V.+r)، شاخص تطبيقى

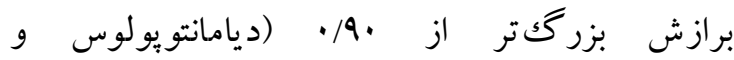

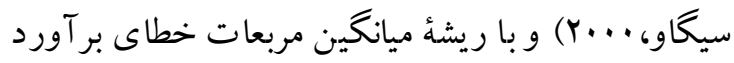

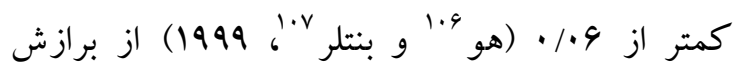
مناسبترى برخوردار است. در مقايسه مدلهاى جهار

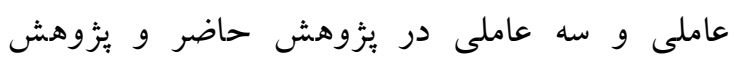

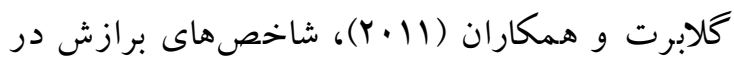

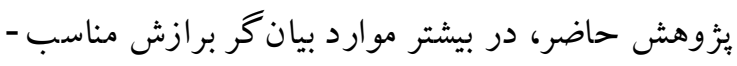
ترى از مدلهاى يادشده هستند؛ مقادير كمتر از بّ براى شاخص خى -روى نسبى و ريشهُ ميانگين مربّعات

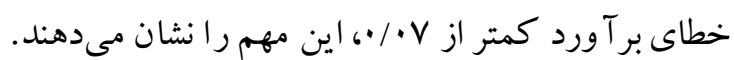
با اين حال، شاخص تطبيقى برازش در تمامى مدلهاى

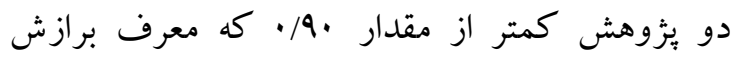

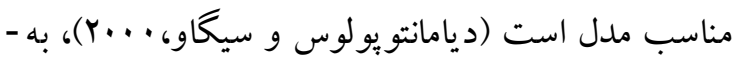
دست آمدهاند.
نتايج مندرج در جدول 9 نشان مىدهد كه مدل 4 عاملى، از شاخص هاى بر ازش مناسبى برخوردار است. در اين مدل، مقدار خى -دوى نسبى، نزديكك به مقدار ب (Y/MA•)

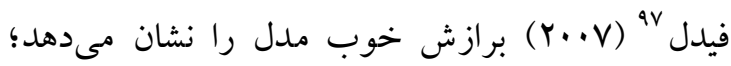

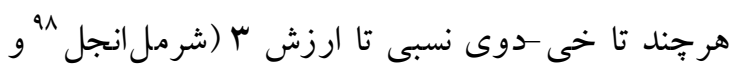

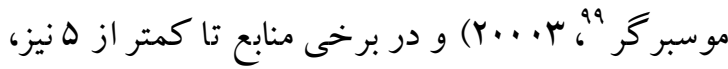

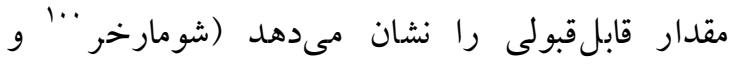

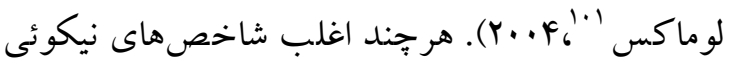
برازش مىبايست به ارزشهايى بيش از •9/• دست

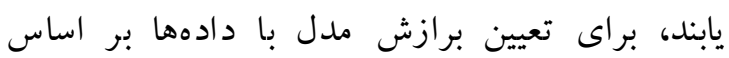

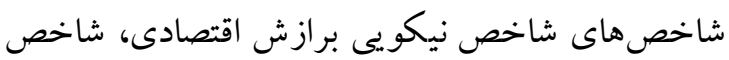
تطبيقى برازش اقتصادى، شاخص هنجارشدهُ برازش اقتصادى (شاخصهاى P P) مولايكك ז'1 و همكاران (1919) ارزش عددى بيشتر از •ه/· • براى شاخصهاى

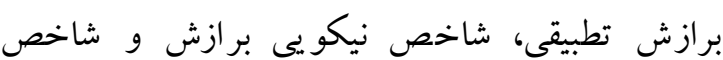
نيكويى برازش اصلاحشده توصيه كردهاند.

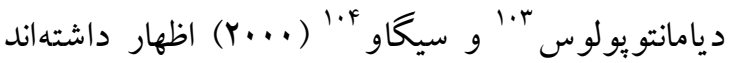
هرجه اين مقادير به ا نزديككتر باشد، وضعيت مطلوب ترى را از بر ازش مدل نشان مىدهد. هم جنين

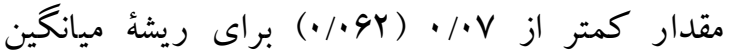

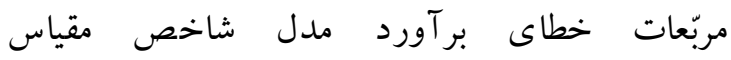

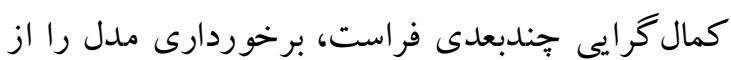

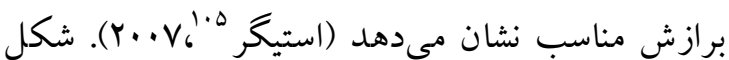

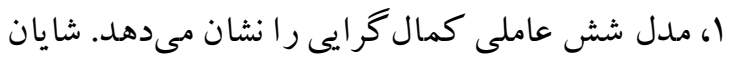
ذكر است، تمامى ضرايب بتا (م) اشارهشده در اين

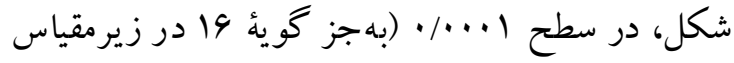

96 . Tabachnick, B. G.

. Fidell, L. S.

98 . Schermelleh-Engel, K.

99 . Moosbrugger, $\mathrm{H}$.

100 . Schumacker, R. E

101 . Lomax, R. G.

102 . Mulaik, S.A.

103 . Diamantopoulos, A.

104 . Siguaw, J.A.

105 . Steiger, J.H. 


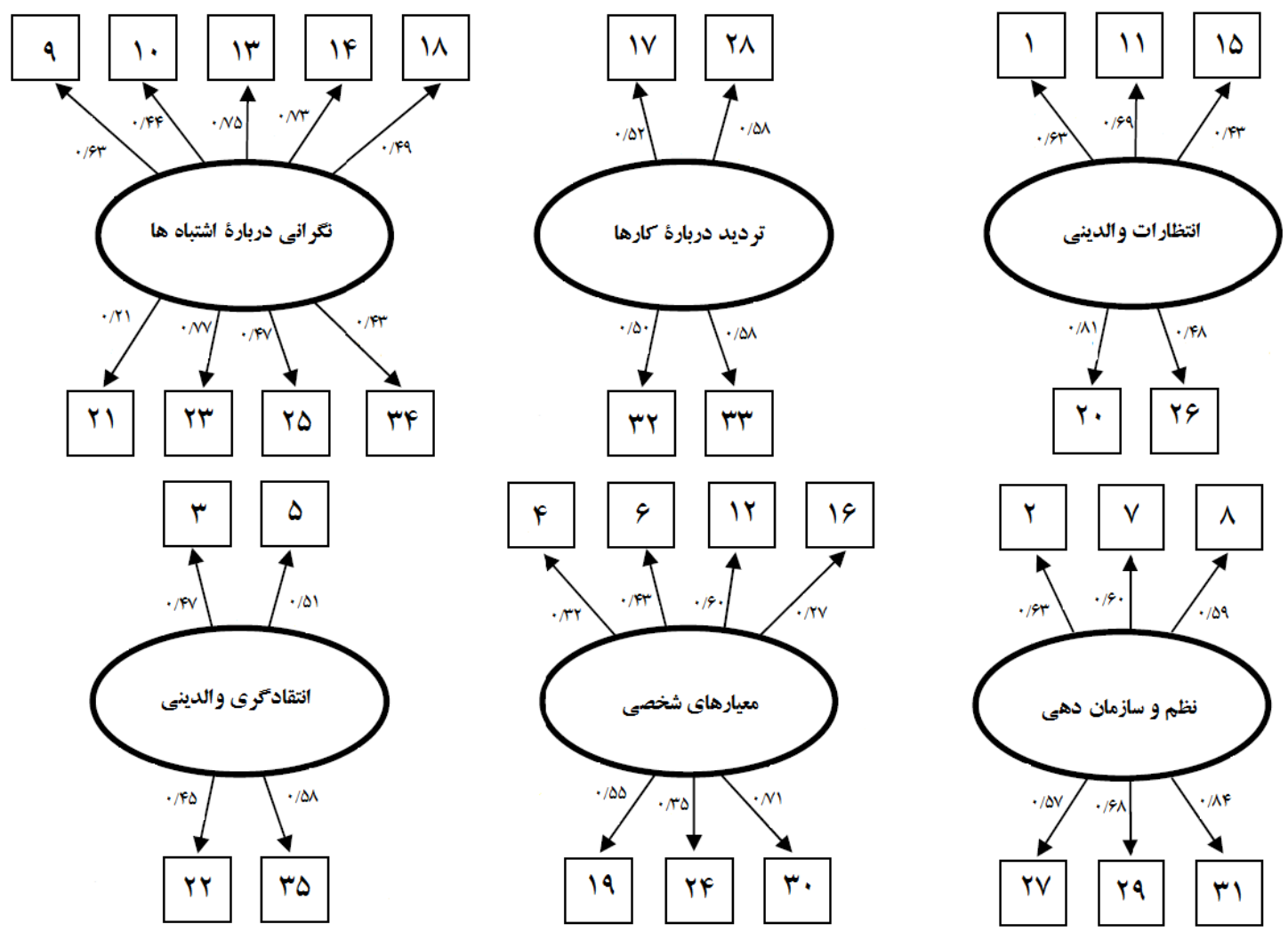

شكل ا مدل ساختارى شش عاملى استاندارد مقياس كمال كرايع جندبعدى فراست

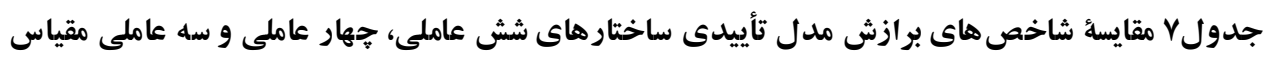

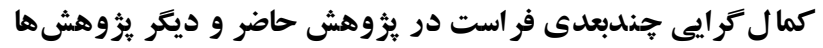

\begin{tabular}{|c|c|c|c|c|c|c|c|}
\hline معنادارى سطح & خطأ ميانكين مربّعات برَّات & شاخص تطبيقى & خسى -دوى & درجهُ آزادى & خى -دو & \multicolumn{2}{|c|}{ شاخص مدل } \\
\hline$\cdot / \cdots \cdot 1$ & $(\cdot / . \Delta \Lambda-.1 .9 \mathrm{~V}) \cdot / .9 \mathrm{Y}$ & - var & $r / M$. & DrA & $110 \% / 10$ & مدل 9 عاملى & يثوهش حاضر \\
\hline$\cdot / \cdots \cdot 1$ & $(\cdot / \cdot 9 \cdot-\cdot . / \cdot v \cdot) \cdot 1 \cdot 90$ & $\cdot / W r$ & Y/YAF & $\Delta F r$ & Irrq/৭qq & مدل F عاملى" & \\
\hline$\cdot / \cdots \cdot 1$ & $(.1 .94-.1 . V \mu) \cdot 1.91$ & $\cdot / \mathrm{VQI}$ & r/raq & $\Delta F \Delta$ & $\mid r \cdot \Delta / M \Lambda$ & مدل ب عاملى"**" & \\
\hline$\cdot / \cdots 1$ & $\left(\cdot / \cdot 4_{-} \cdot / \cdot V\right) \cdot / \cdot V$ & $\cdot / \mathrm{AV}$ & r/qY & $\Delta F \Delta$ & $19 V r / F T$ & مدل 9 عاملى & يخوهش كملابرت \\
\hline$\cdot / \cdots 1$ & $\left(\cdot / \cdot v_{-} \cdot \cdot / \cdot \Lambda\right) \cdot / \cdot \Lambda$ & - & $F / F$. & $\Delta \Delta F$ & YFTD/rY & مدل F عاملى" & $(r \cdot 11)$ \\
\hline$\cdot / \cdots 1$ & $\left(\cdot / \cdot q_{-} \cdot / 1 \cdot\right) \cdot / 1 \cdot$ & $\cdot M^{F}$ & $9 / \pi V$ & $\Delta Y F$ & rMra/vo & مدل r عاملى"*" & \\
\hline$\cdot / \cdot \cdot 1$ & $\cdot 1 \cdot+4 \Delta$ & $\cdot / 99$ & $1 / 994$ & IVr & raY/Ar & مدل 9 عاملى & $\begin{array}{c}\text { يخوهش كوريا } \\
(r+1 Y)\end{array}$ \\
\hline
\end{tabular}

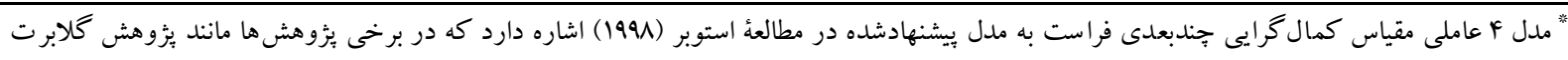

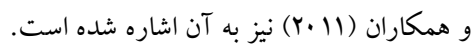

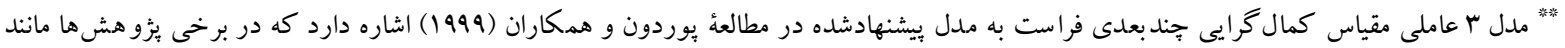

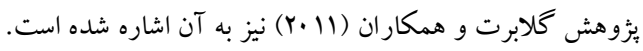


كرايى جندبعدى فراست، از قبيل ضريب آلفاى كرونباخ و بررسى اعتبار سازه از طريق تحليل عاملى

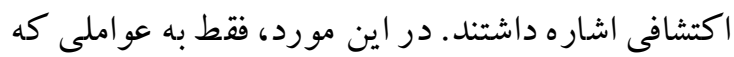
بهدست آمده (شامل ^ عامل ) اشاره شده است. لياقت و

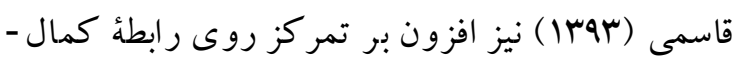
كرايى و اضطراب امتحان و تأثير آنها بر يكديخر،

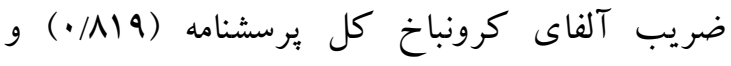

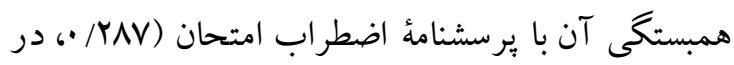

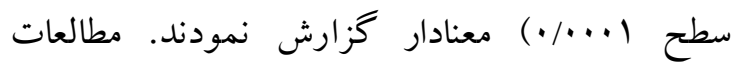
داخلى يادشده، در گزارش ويزگى هاى روانسنجى

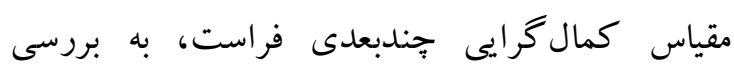
شاخص هاى محدودى از اعتبار و يايايى اشاره داشتهاند.

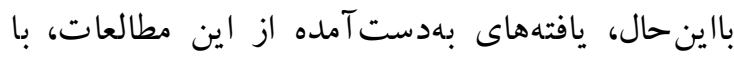
يافتهاى حاصل از ئزوهش حاضر، همخر ايى دارد. همبستكى بين زيرمقياسهاى مقياس كمال كرايى

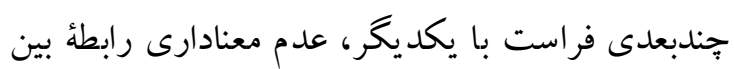

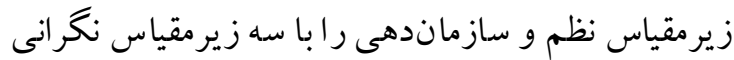

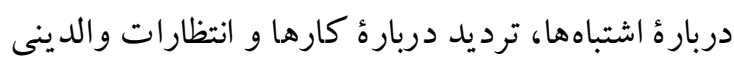
را نشان داد. اين يافته با يافتهاى كوريا و همكاران

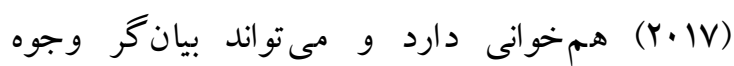

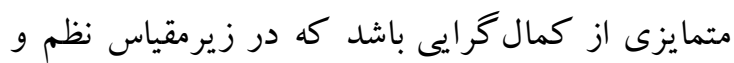
سازماندهى نسبت به ديخر زيرمقياس هاى يادشده طرح

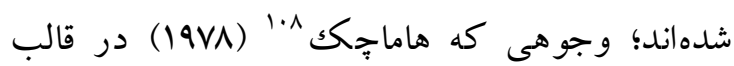
بيوستار بين كمال گرايى بهنجار تا كمال گرايى نابهنجار

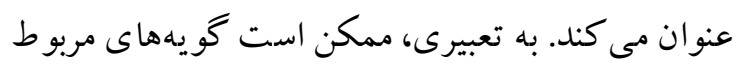

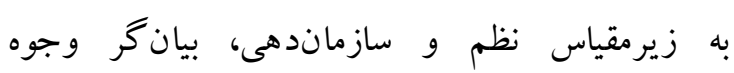
بهنجارترى از كمال باشند. ارزيابى اعتبار همگراى مقياس كمال گرايى جندبعدى فراست، با استفاده از بر سشنامهٔ تجارب مربو ط به رو ابط ابط

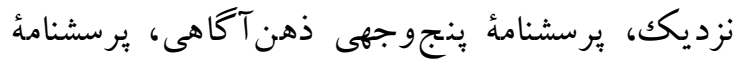

108. Hamachek, D. E.

\section{بحث}

بثوهش حاضر با هدف تعيين اعتبار و بِايايى مقياس كمال كرايى جِندبعدى فراست در نمونهُ غير بالينى ايرانى طراحى و اجرا شد. مقايسٔ ميانگينهاى مربوط به زيرمقياسهاى مقياس كمال گر ايى جندبعدى فراست در بثزوهشهاى انجامشده، در اغلب موارد، نشانكر تفاوت بين ميانخين هاى بهدست آمده از ئزوهش حاضر

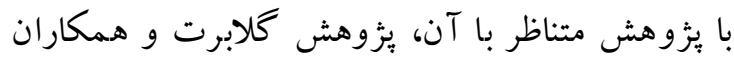

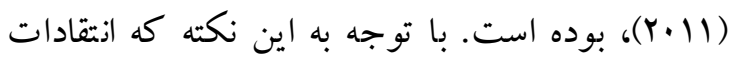

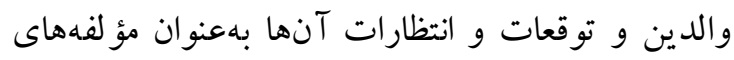
مهم كمال گرايى در نظر گرفته شدهاند و والدين كمال - ونمال كرا با امتناع از تأييد رفتار فرزندان خود و دور در مقابل،

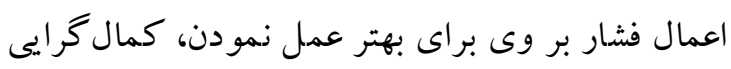
را در فرزند خود تقويت مىكنند (فراست و همكار ان، • 199)، به نظر مىرسد شيوه تربيت و نوع برخو رد والدين با عملكرد فر زند خود كه عاملى شد يداً

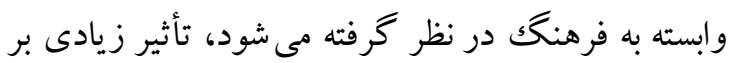

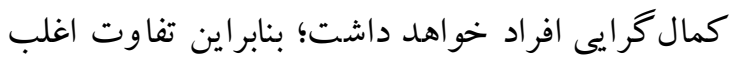
ميانگينهاى بهدست آمده در يزوهش حاضر نسبت به

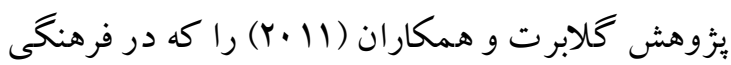

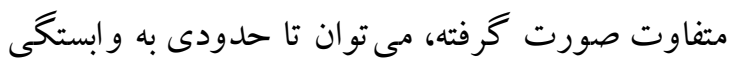
كمال گر ايى به فرهنگ نسبت د اد. بهعلاو ه، ممكن است

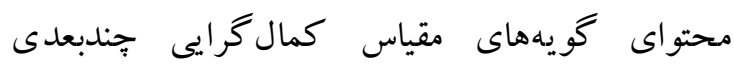
فراست در ايجاد جنين تفاوتى مؤثر باشد و استفاده از ابزارهاى ديخرى كه شمار محدودترى از زيرمقياس هاى كمال گرايى را در نظر مى گيرند و به نشانهاى دهاى

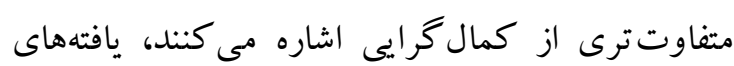
متمايزى رابه دست دهد. در ميان يُزوهشهاى داخلى كه به وارسى ويزّكى

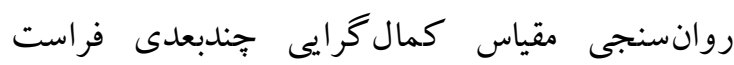

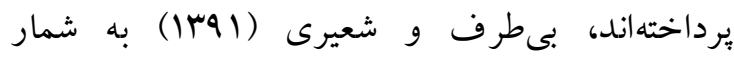
محدودى از ويزگىهاى روانسنجى مقياس كمال - 
اغلب مو ارد، همبستخىها معنادار كزارش نمود.

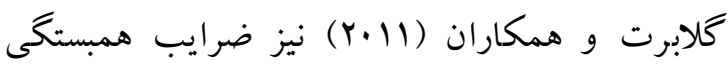

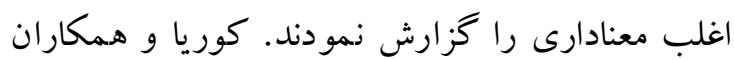
(Y.IV)

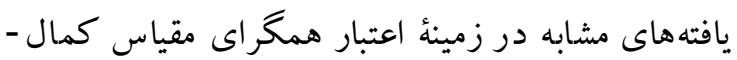

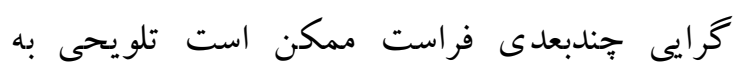
برخوردارى گويههاى اين مقياس از وجوه مشابه يا معانى نزديكى در نمونها و فرهنگك هاى مختلف داشته باشد و يا فرايندهاى مشابهى را در بر داشته باشد كه در رابطه با متغيرها و ابزارهاى انتخابشده در هر مطالعه

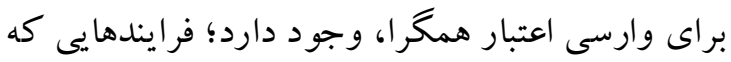
شناخت آنها، متضمن يزوهشئه هايى در زمينهُ مزبور

در بررسى بايايى مقياس كمال گرايى جندبعدى

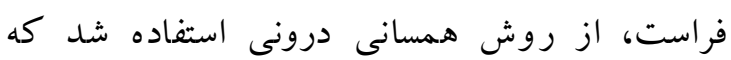
ضرايب آلفاى كرونباخ بين سو/· براى ترديد دربارهٔ

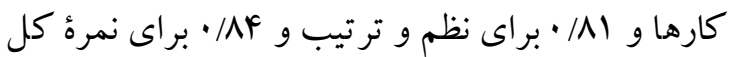

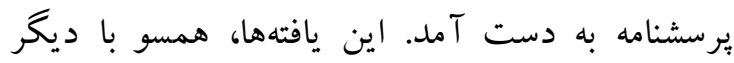
يثوهشهاى انجامشده در اين زمينه بوده است

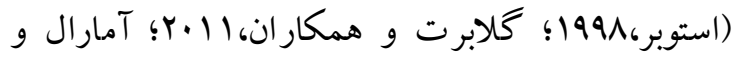

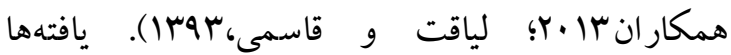
برخوردارى برسشنامه از پيايايى مناسب را هم در يثزوهش حاضر و هم در مطالعات مرور شده، نشان مى دهند. در ميان زيرمقياسهاى FMPS، به نظر مىرسد ترديد درباره كارها، از كمترين و نظم و سازماندهى از

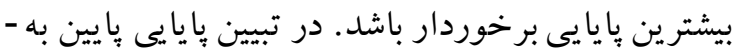
دست آمده براى زيرمقياس ترديد درباره كارها در جند تهند

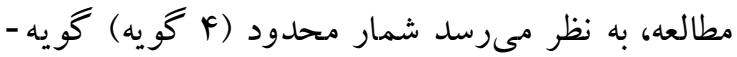
هاى اين زيرمقياس نسبت به زيرمقياسهاى ديخر مقياس كمال گرايى جندبعدى فراست، در ميزان اين

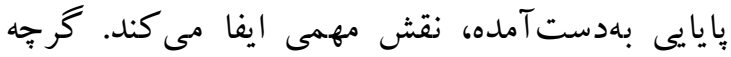
زيرمقياس انتقادگرى والدينى نيز در اين مقياس همين
كو تاه نظمجويى شناختى هيجان و مقياس افسردگى، اضطراب و استرس صورت گرفت كه اغلب ضرايب

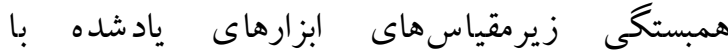
زيرمقياسهاى كمال گرايى، معنادار به دست آمدندئ.

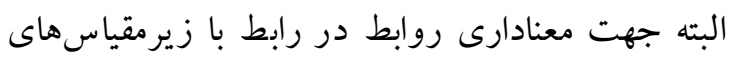

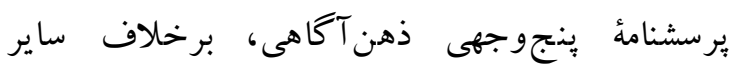

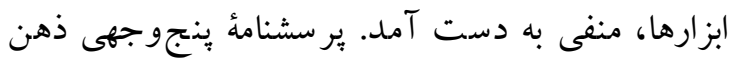
آكاهى به سنجش مهارتهاى ذهن آكاهى، بهعنوان

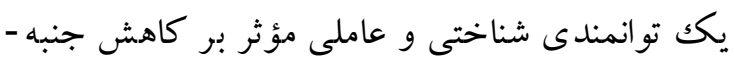

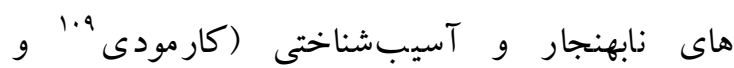

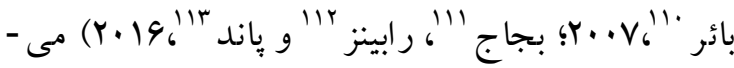
بردازد. از اين رو به نظر مىرسد وجود رابطة منفى بين زيرمقياس هاى اين برسشنامه و زيرمقياس هايى از مقياس

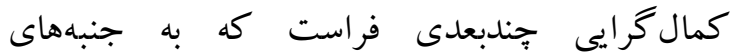
نابهنجارتر كمال گرايى مانند نغرانى درباره اشتباهها، ترديد دربارهٔ كارها، انتظارات والدينى و انتقادگرى ماند والدينى اشاره دارند، طبيعى باشد. اين در حالى است كه ديخر ابزارها، بهصورت غالب، به سنجش جنبه آهاى آسيبشناختى روان مىيردازند و در مو ارد وجود رابطة

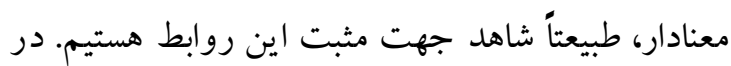
مجموع معنادارى بين زيرمقياسهاى ابزارهاى استفاده - ماسئ شده در بززوهش حاضر همراه با مقياس كمال گرايى جندبعدى فراست، بيان گر اين امر است كه اين مقياس از اعتبار همخراى مناسبى در نمونهُ مورد مطالعه برخوردار است. اين يافتها، همسو با يافتهاى ديخر

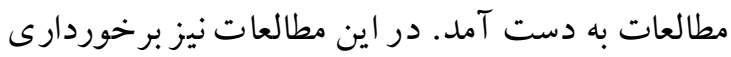
مقياس كمال گرايى جندبعدى فراست را از اعتبار همخراى مناسب نشان مىدهد. بهعنوان نمونه، استوبر

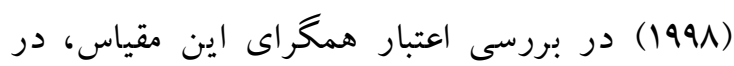

\footnotetext{
109 . Carmody, J

110 . Baer, R. A.

111 . Bajaj, B.

112. Robins, R. W.

${ }_{113}$ Pande, N.
} 
را از قابليت اعتماد بيشتر نسبت به ساير FMPS ساختارها بيان كند. با اين وجود، اختلافنظر در زمينهُ ساختار عاملى با تعداد عوامل متفاوت ادامه دارد و بيشنهاد مىشود يُزوهش هاى عميقترى با استفاده از

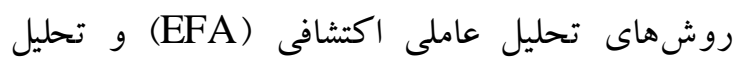
عاملى تأييدى (CFA) بهصورت تو أمان روى نمونههاى كستردهتر و با تنوع ويز گیىهاى جمعيت شناختى و مقايسه و تلفيق يافتها براى دستيابى به نتايج جامع تر،

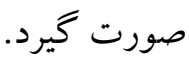

\section{نتيجه كيرى}

يُوهش حاضر با هدف بررسى اعتبار و بايايى مقياس

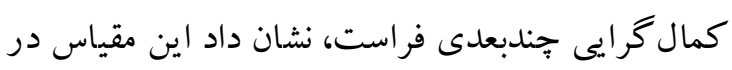

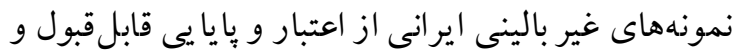
مناسبى برخوردار است.

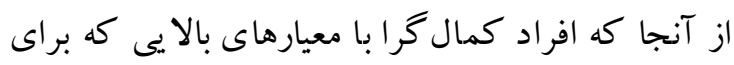

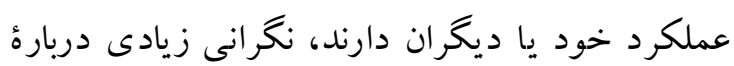

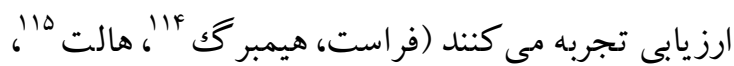

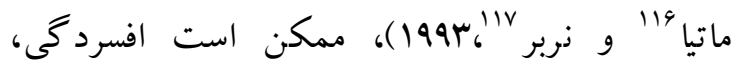
اضطر اب و يا ساير ناخوشىهاى روانشناختى را تجربه نمايند. با تو جه به اين كه امروزه كمال گرايى بهعنوان

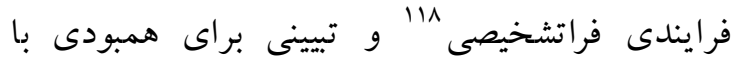

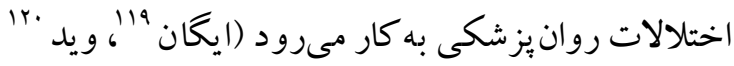

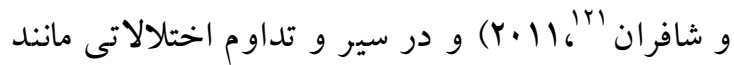
افسردكى، اضطراب و اختلالات خوردن نقش دارد ورد (شافران و مانسل، (Y...)، به نظر مىرسد توجه به كمال گرايى در برنامههاى مربوط به سنجش و درمان جنبهاى ناساز گارانهُ روان، كام مؤثرى در جرهت

\footnotetext{
${ }^{114}$. Heimberg, R. G.

115 . Holt, C. S.

116 . Holt, C. S.

117. Neubauer, A.L.

118. Transdiagnostic process

119 . Egan, S. J.

${ }_{120}$. Wade, T.D

121 . Shafran, R
}

تعداد گويه دارد، ممكن است اشاره گويههاى مربوط

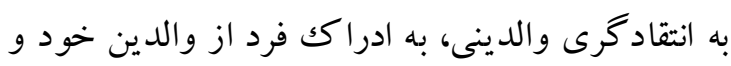

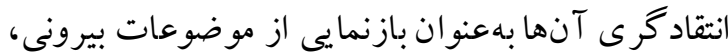

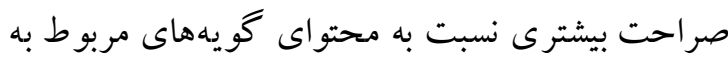
زيرمقياس ترديد درباره كارها كه به عدم اطمينان، ترديد و تكرار اشاره مى كند، براى شركت كنند داشته باشد و همين امر به تفاوت مشاهده شد در ميزان جايايى دو زيرمقياس كوتاه (با كمترين تعداد گويه)

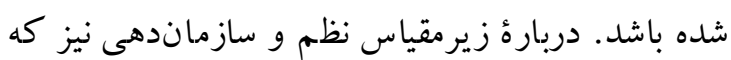
بيشتر ين ميزان بايايى را نشان داد، نيز ممكن است تأكيد بر مفاهيمى جون تميزى، نظم و ترتيب، قائل بودن به

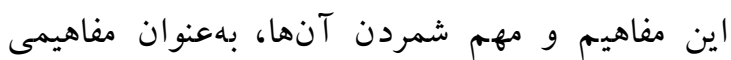

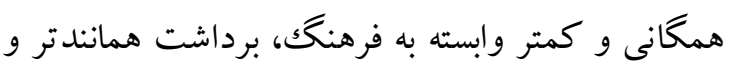
عينى ترى براى شركت كنند كان داشته كه به هنين يافتهاى منتهى شده است. در زمينهُ بررسى اعتبار سازه و ساختار عاملى مقياس كمال گرايى جندبعدى فراست، ساختار شش عاملى ييشنهادشده توسط فراست و همكاران (.199) در يزوهش حاضر، هم سو با مطالعات كابلرت و همكاران

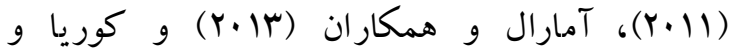

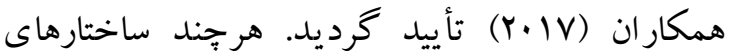
جهار عاملى (استوبر،1991) و سه عاملى (يوردون و همكار ان،9991) مورد بررسى در يزوهش حاضر، شاخصهاى برازش قابلقبولى از خود نشان دادند؛ بـ اين حال، ساختار اولية شش عاملى كه در ابتدا فراست و همكاران (1999) ضمن تدوين مقياس بيشنهاد نمودند، برازش مناسب ترى را هم در يثوهش حاضر و

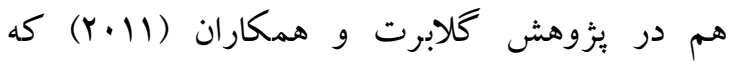
همزمان به هر سه ساختار برداخته بودند، نشان مىدهد. در دو مطالعهُ يادشده، ساختار جهار عاملى نسبت به ساختار سه عاملى از برازش مناسبترى بود. اين امر ممكن است برخوردارى ساختار شش عاملى استاندارد 
anxiety and stress (DASS) scales in nonclinical samples. Daneshvar e Raftar. 38:2331. [inPersian]

Baer, R. A.: Smith, G. T.; Allen, K. B. (2004). Asessment of Mindfulness by Self-Reports the Kentucky Inventory of Mindfulness Skills. Journal of Assessment. 11(3): 191206.

Bajaj, B.; Robins, R. W.; Pande, N. (2016). Mediating Role of Self-Esteem on the Relationship between Mindfulness, anxiety and Depression. Journal of Personality and Individual Differences. 94:127-131.

Besharat, M. A. (2016). Cognitive Emotion Regulation: Performance and Scoring method. Journal of Developmental Psychology: Iranian Psychologists. 50 (10)221-223. [in Persian]

Bitaraf, S.; Shairi, M. R. (2012). The Investigation of Factorial Structure of Frost Perfectionism Scale (FMPS) in Student Sample. Sixth Seminar ofStudents' Mental Health. Guilan University. [inPersian]

Brennan, K. A.; Clark, C. L.; Shaver, P. R. (1998). Self-report measurement of adult attachment: An integrative overview. In L. A. Simpson \&W. S. Rholes (Eds.), Attachment theory and close relationships. New York: Guilford Press.

Brown, K. W. \& Ryan, R. M. (2003). The benefits of being present: Mindfulness and its role in psychological wellbeing. Joumal of Personality and Social Psychology.84: 822848.

Browne, M. W.; Cudeck, R. (1993). Altemative Ways of Assessing ModelFit. In Bollen, K. A. \& Long J. S. (Eds). Testing Structural Equation Models. (pp819-831). Newbury Park, CA: Sage.

Carmody, J.; Bear, R. A (2007). Relationship between mindfulness practice and level of mindfulness, medical and psychological symptoms and well-being in a mindfulness stress reduction program Journal of Behavioral Medicine.31:23-33.

Cebolla, A.; García-Palacios, A.; Soler, J.; Guillen, V.; Baños, R.; Botella, C. (2012). Psychometric Properties of the Spanish Validation of the Five Facets of Mindfulness Questionnaire

$$
\begin{aligned}
& \text { ارتقاى سطح سلامت روان جامعه باشد. از اينرو } \\
& \text { بررسى اعتبار و بايايى ابزارهايى مانند مقياس كمال - } \\
& \text { گرايى جندبعدى فراست، امكان سنجش كمال } \\
& \text { را بهعنوان راهى براى ورود اين سازهُ روانشناختى مؤثر }
\end{aligned}
$$

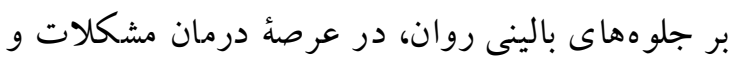

$$
\begin{aligned}
& \text { اختلالات روانشناختى و بهبود سلامت روان فراهم } \\
& \text { مى كند. } \\
& \text { سياسگز ارى } \\
& \text { سياس صميمانه از تمامى دانشجويان شركت كنئنده در } \\
& \text { يثزوهش، اساتيد محترم و مسئولان دانشگاه شاهد كه }
\end{aligned}
$$

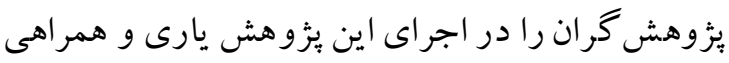

$$
\begin{aligned}
& \text { نمودند. }
\end{aligned}
$$

\section{Refrences}

Ahmadvand Z, Heydarinasab L, Shairi MR. (2013) Checking Validity and Reliability of the Five-Facet Mindfulness Questionnaire (FFMQ) in Iranian Non-Clinical Samples. Joumal of Behavioral Sciences. 3(7):229238. [inPersian]

Amaral A. P. M; Soares, M. J.; Pereira, A. T.; Bos, S. C.; Marques, M; Valente, J.; Nogueira, V.; Azavedo, M. H.; Macedo, A. (2013). Frost Multidimensional Perfectionism Scale: the Portuguese Version. Joumal of Revista de Psiquiatria Clínica. 40(4):144149.

Antony, M. M.; Purdon, C. L; Huta, V.; Swinson, R. P. (1998). Dimensions of Perfectionism across the Anxiety disorders. Joumal of Behavior Research and Therapy. 36(12):1143-1154.

Aref Nia, R; Ghamari, M. (2015). The Relationship between Mindfulness and Perfectionism with Obsessional Thoughts in Psychology Students of Karaj Branch of Islamic Azad University. National Congress of Psychology and Management of Social Pathologies.

Asghari Moghaddam MA; Sa'ed F; Dibaj Nia P, Zangeneh J. (2008). Preliminary evaluation of validity and reliability of depression, 
(FFMQ). 2(26):118-126. Europian Journal of Psychiatry

Chadwick, P.; Hember, M.; Symes, J.; Peters, E.; Kuipers, E; Dagnan, D. (2008). Responding Mindfully to Unpleasant Thoughts and Images: Reliability and Validity of the Southampton Mindfulness Questionnaire (SMQ). British Journal of Clinical Psychology. 47:451-455.

Cheng S.K., Chong, G.H., \& Wong, C.W. (1999). Chinese frost multidimensional perfectionism scale: A validation and prediction of selfesteem and psychological distress. Journal of Clinical Psychology. 55(9): 1051-1061.

Correia, M.; Rosado, A.; Serpa, S. (2017). Psychometric Properties of the Portuguese Version of the Frost Multidimensional Perfectionism Scale. International Journal of Psychological Research. 10(1):8-17.

Cox, B.J.; Enns, M.W.; Clara, I.P. (2002). The multidimensional structure of perfectionism in clinically distressed and college student samples. Psychological Assessment. 14(3):365-373.

Dakanalis, A.; Timko, C. A.; Zanetti, M. A.; Rinaldi, L.; Prunas, A.; Cannà, G.; Riva, G.; Clerici, M. (2014). Attachment Insecurities, Maladaptive Perfectionism, and Eating Disorder Symptoms: A Latent Mediated and Moderated Structural Equation Modeling Analysis across Diagnostic Groups. Joumal of Psychiatry Research 215:176-184.

Diamantopoulos, A.; Siguaw, J.A. (2000). Introducing LSREL. London: Sage Publications.

Egan, S.J.; Wade, T.D.; Shafran, R. (2011). Perfectionism as a Trans-Diagnostic Process: A Clinical Review. Journal of Clinical Psychology Review. 31(2):203212.

Feldman, G.; Hayes, A.; Kumar, S.; Greeson, J.; Laurenceau, J. P. (2007). Mindfulness and Emotion Regulation:The Developmant and Initial Validation of the Cognitive and Affective Mindfulness Scal-Revised (CAMS-R). Journal of Psychopahology and Behavioral Assessment. 29:177-190.
Flett, G. L; Davis, A. R.; Hewitt, L. P. (2003). Dimension of Perfectionism, Unconditional Self-Acceptance, and Depression. Journal of Rational-Emotive and Cognitive-Behavior Therapy. 2(21):119-139.

Fraky, R. C. (2005). Information on the Experiences in Close Relationships-Revised (ECR-R) Adult Attachment Questionnaire. Available at:

http//www.psychuiuc.edv/ rcfraley/measu res/ecrr.htm

Fraky, R. C.; Waller, N. G.; Brennan, K. A. (2000). An Item-Response Theory Analysis of Self Report Measure of Adult Attachment. Joumal of Personality and Social Psychology. 78:350-365.

Franco, K.; Díaz, F.; Tomes, P.; Tellez, Y.; HidalgoRasmussen, C. (2014). Intemal consistency, test-retest reliability and construct validity of the Frost Multidimensional Perfectionism Scale. Mexican Journal of Eating Disorders. 5:91-97.

Franko, K.; Mancilla,-Díaz, J.; Vázquez, R.; Álvarez, G.; López, X. (2010). Estructura factorial y consistencia interna de la escala Multidimensional de Perfeccionismo. Joumal of Revista Mexicana de Psicología. 27:143-149.

Frost, R. O.; Heimberg, R. G.; Holt, C. S.; Mattia, J. I; Neubauer, A. L. (1993). A Comparison of Two Measures of Perfectionism Journal of Personality and Individual Differences.14 (1):119-126.

Frost, R. O.; Marten, P.; Lahart, C.; Rosenblate, R. (1990). The Dimensions of Perfectionism Joumal ofCognitive Therapy and Research 14:499-462.

Garnefski N, Kraaij V, Spinhoven P. Negative life events, cognitive emotion regulation and emotional problems. (2001). Journal of Personality and Individual Differences. 30(8): 1311-1327.

Garnefski N, Kraaij V. Cognitive emotion regulation questionnaire - development of a short 18item version (CERQ-short).(2006). Joumal of Personality and Individual Differences. 41(6): 1045-53.

Gavino, A.; Nogueira, R.; Pérez-Costillas, L; Godoy, A. (2017). Psychometric Properties of the Frost Multidimensional Perfectionism Scale 
in Spanish Children and Adulescents. Journal of assesment. 0:1-20. Retrieved at sagepub.comjournalsPermissions.nav. DOI:10.1177/1073191117740204.

Gelabert, E; García-Esteve, L; Martín-Santos, R.; Gutiérez, F.; Torres, A. (2011). Psychometric Properties of the Spanish Version of the Frost Multidimensional Perfectionism Scale in Women. Journal of psicothema. 1(23):133-139.

Hamachek, D.E. (1978). Psychodynamics of normal and neurotic perfectionism psychology. Joumal of Human Behavior. 15:27-32

Harvey, B.; Pallant, J.; Harvey, D. (2004). An evaluation of the factor structure of the Frost Multidimensional Perfectionism Scale. Joumal of Educational and Psychological Measurement. 64:1007-1018.

Hassani, J. (2011). The examination of Reliability and Validity of Short Form of Cognitive Emotion Regulation. Journal of Behavioral Sciences Research 4 (9): 229-240. [in Persian]

Hawkins, C.C.; Watt, H.MG.; Sinclair, K.E. (2006). Psychometric properties of the frost Multidimensional Perfectionism Scale with Australian adolescent girls: Clarification of multidimensionality and perfectionist typology. Educational and Psychological Measurement. 66(6): 1001-1022.

Henry, J. and Crawford, J. R. (2005). The short-form version of the Depression Anxiety stress scales (DASS-21). The British Journal of clinical psychology. 44:227-239.

Hewitt, P.L.; Flett, G.L. (1991). Perfectionism in the self and social contexts: Conceptualization, assessment and association with psychopathology. JournalofPersonality and Social Psychology. 60(3) :456-470.

Hu, L. T.; Bentler, P. M. (1999). Cut off Criteria for Fit Indexes in Covariance Structure Analysis: Conventional Criteria Versus New Altematives. Joumal of Structural Equation Modeling. 1:8-38.

Khawaja, N. G.; Armstrong, K. A. (2005). Factor structure and psychometric properties of the frost Multidimensional Perfectionism Scal: Developing shorter versions using an Australian sample. Australian Joumal of Psychology. 57:129-138.
Liaghat, R.; Ghasemi, F. (2014). The Examination of Psychometric Properties of Frost Perfectionism Questionnaire and its Relationship with Examination Anxiety (Case Study:Tehran High Schools). Journal of Psychological Research. 23 (6):60-76.

Macedo, A.; Marques, M; Pereira, A. T. (2014). Perfectionism and PsychologicalDistress: A Review of the Cognitive Factors. Joumal of Clinical Neurosciences and Mental Health 6(1):1-10.

Mulaik, S.A.; James, L.R.; Van Alstine, J.; Bennet, N.; Lind, S.; Stikell, C.D. (1989). Evaluation of Goodness-of-Fit Indices for Structural Equation Models. Psychological Bulletin. 105 (3): 430-45.

Nilsson, K.; Sundbom, E; Hägglöf, B. (2008). A longitudinal study of perfectionism in adolescent onset anorexia nervosa-restricting type. European Eating Disorders Review. 16(5):386-394.

O'Connor, D. B.; O'Connor, R. C.; Marshal, R. (2007). Perfectionism and Psychological Distress: Evidence of the Mediating Effects of Rumination. European Joumal of Personality. 21:429-454.

Panaghi L, Maleki G, Zabih Zadeh A, Psht Mohammadi M, Soltani Nethad Z (2013). Validity, reliability and factorial structure of Experiences in Close Relationship (ECR). Psychiatry and Clinical Psychology of Iran 4(19):305-313. [in Persian]

Park, H. J.; Heppner, P. P.; Lee, D. G. (2010). Maladaptive Coping and Self-Esteem as Mediators between Perfectionism and Psychological Distress. Journal of Personality and Individual Differences. 4(48):469-474.

Purdon. C.; Antony, M. M.; Swinson, P. R. (1999). Psychometric properties of the Frost Multidimensional Perfectionism Scale in Clinical anxiety disoder sample. Journal of ClinicalPsychology. 55:1271-1286.

Rhéaume, J.; Freeston, M. H.; Dugas, M. J.; Letarte, H.; Ladouceu, R. (1995). Perfectionism, responsibility, and obsessive-compulsive symptoms. Journalof behavior research and therapy. 33:785-795.

Rotanu, S. T.; Rusu, A. (2013) Psychometric Properties of Romanian Version of 
Experiences in Close RelationshipsRevised Questionnaire (ECR-R). Joumal of Social and Behavioral Sciences. 7851-55.

Rudolph, S. G.; Fett, G.L; Hewitt, P. L. (2007). Perfectionism and Deficits in Cognitive Emotion Regulation Joumal of Rational Emotional Cognitive Behavior Therapy. 25(4):343-357.

Sahebi A, Asghari MJ, Salari RS. Validation of depression anxiety and stress scale (DASS21) for an Iranian population.(2005). Iranian Psychologists. 4(1):299-313.

Schermelleh-Engel, K.; Moosbnugger, H. (2003). Evaluating the fit of structural equation models: tests of significance and descriptive goodness-of-fit measures. Methods of Psychological Research Online. 8(2)23-74.

Schumacker, R. E., \& Lomax, R. G. (2004). A beginner's guide to structural equation modeling. Second edition London: Routledge.

Shafran, R.; Mansell, W. (2001). Perfectionism and Psychopathology: A Review of Research and Treatment. Journal of Clinical Psychology Review. 21(6):879-906.

Steiger, J.H. (2007). Understanding the limitations of global fit assessment in structural equation modeling. Joumal of Personality and IndividualDifferences. 42(5):893-98.

Stöeber, J. (1998). The Frost multidimensional perfectionism scale revisited: More perfect with four (instead of six) dimensions. Personality and Individual Differences. 24(4):481-491.

Tabachnick, B. G.; Fidell, L. S. (2007). Using Multivariate Statistics ( $5^{\text {th }}$ ed.). New York: Allyn and Bacon.

Tery-Short, L. A.; Owens, R.G.; Salde, P. D.; Dewey, M.E (1995). Positive and negative perfectionism Joumal of Personality and IndividualDifferences. 18:663-668.

Walach, H.; Bechheld, N.; Buttenmiiller, V.; Kleinknecht, N.; Schmidt, S. (2006). Measuring Mindfulness-Freiburg Mindfulness Inventory (FMI). Joumal of Personality and Individual Differences. 40:1543-1555.

Yousefi, E; Azadeh, S. M.; Majlesi, Z; Salehi, A. (2016). The Effectiveness of MindfulnessBased Cognitive Therapy (MBCT)
Intervention on Mental Ruminations, Metacognitive Beliefs, and Perfectionism in Patients with Obsessive-Compulsive Disorder in Isfahan International Journal of Humanities and Cultural Studies. (Retrieved May 19, 2017, on the World Wide Web: https $/ /$ www.ijhcs.com/index.php/ijhcs/articl e/download/1806/1506). 